\begin{tabular}{llllllll}
\hline $\mathrm{A}$ & $\mathrm{R}$ & $\mathrm{T}$ & $\mathrm{Y}$ & $\mathrm{K}$ & $\mathrm{U}$ & $\mathrm{E}$ & $\mathrm{Y}$
\end{tabular}

WŁODZIMIERZ GOGEOZA

https://orcid.org/0000-0002-0931-7413

Uniwersytet Marii Curie-Skłodowskiej

\title{
ISLANDZKA GOSPODARKA W OKRESIE WOLNEJ WSPÓLNOTY
}

Zarys treści: $\mathrm{W}$ artykule omówiono islandzka gospodarkę w okresie od zasiedlenia wyspy aż po kres funkcjonowania tzw. Wolnej Wspólnoty (ok. 930-1264). Dzięki analizie treści staroislandzkich źródeł narracyjnych i prawnych oraz wyników badań archeologicznych odtworzono strategie adaptacyjne osadników do warunków naturalnych wyspy, zrekonstruowano średniowieczną islandzką strukturę społeczna, z uwzględnieniem relacji pracowniczych, zarysowano gospodarkę hodowlaną oraz wewnętrzny i zewnętrzny obieg towarowo-pieniężny.

The content outline: The article deals with the Icelandic economy from the time of the settlement to the fall of the so-called Commonwealth (ca. 930-1264). Using the extant narrative and legal Old Icelandic sources, as well as the results of modern archaeological research, the article describes the settlers' adaptation strategies, reconstructs the medieval Icelandic social structure and work relations, and recreates the farming strategies, as well as the inner and outer circulation of goods and money.

Słowa kluczowe: Islandzka Wolna Wspólnota, zasiedlenie Islandii, historia gospodarcza Islandii, wymiana gospodarcza, środki płatnicze

Keywords: Icelandic Commonwealth, settlement of Iceland, economic history of Iceland, economic exchange, payment methods

Islandia została zasiedlona na przełomie IX i X w. przez skandynawskich osadników, z których najbardziej prominentni pochodzili z terenów południowo-zachodniej Norwegii ${ }^{1}$. Okres „objęcia ziemi” (landnám)

${ }^{1}$ P. Urbańczyk, Na tropie pierwszego Islandczyka, w: Hominem quaerere. Człowiek $w$ źródle historycznym, red. S. Rosik, P. Wiszewski, Wrocław 2009, s. 69-77. 
tradycyjnie datowany jest w islandzkiej historiografii na lata ok. 870-ok. 930 i za jego symboliczne zakończenie uznaje się ukonstytuowanie przez kolonistów Zgromadzenia Powszechnego, dorocznego wiecu sądowo-legislacyjnego, na którym spotykali się lokalni wodzowie wraz ze stowarzyszonymi z nimi wolnymi gospodarzami ${ }^{2}$. Przez kolejnych 300 lat Islandczycy tworzyli przedpaństwową społeczność w modelu wodzowskim ${ }^{3}$, określaną współcześnie mianem Wolnej Wspólnoty (Pjódveldið) ${ }^{4}$. Kres jej funkcjonowania nastapił w 1264 r., kiedy mieszkańcy wyspy poddali się władzy norweskiego króla Magnúsa VI, wskutek czego Islandia stała się obszarem trybutarnym Norwegii ${ }^{5}$.

Warunki, w jakich przyszło egzystować średniowiecznym Islandczykom były ciężkie. Mimo znacznej powierzchni wyspy jedynie jej pas przybrzeżny nadaje się do produktywnego zagospodarowania, a relatywnie niska jakość gleb poddawanych ciagłej erozji wietrznej wykluczała na większości terenów możliwość uprawy roli. Ograniczony wachlarz zasobów naturalnych sprawiał z kolei, że większość surowców, niemal wszystkie towary luksusowe i znaczna część dóbr użytkowych musiała być przez wyspiarzy importowana. Znaczny stopień izolacji geograficznej istotnie utrudniał im przy tym wymianę handlowa, która z uwagi na techniczne ograniczenia żeglugi dalekomorskiej miała sezonowy charakter. Jednak mimo materialnego ubóstwa średniowieczni Islandczycy pozostawili po sobie imponujacy dorobek kulturowy, który od dziesięcioleci fascynuje przedstawicieli różnych dyscyplin naukowych ${ }^{6}$.

Ekonomiczny wymiar islandzkich wodzostw doczekał się w literaturze wielu opracowań, w których szczegółowej ewaluacji poddano

${ }^{2}$ Odnośnie do przebiegu zasiedlenia Islandii zob. O. Vésteinsson, The Archeology of Landnám. Early Settlement in Iceland, w: Vikings. The North Atlantic Saga, red. W. Fitzhugh, E. Ward, Washington 2000, s. 165-174; P. Urbańczyk, Zdobywcy pótnocnego Atlantyku, Toruń 2012, s. 69-78.

${ }^{3}$ Ogólnie na temat systemu wodzowskiego zob. A. Ciesielska, Królestwo, państwo, wodzostwo czy system prawa ksiażęcego? O formach organizacji społecznych na etapie wczesnopaństwowym kilka uwag teoretycznych, „Studia Lednickie” 11, 2012, s. 51-53; o ustroju Pjódveldið zob. B. Runólfsson-Solvason, Ordered Anarchy. Evolution of the Decentralized Legal Order in the Icelandic Commonwealth, „Journal des Économistes et des Études Humaines" 3, 1992, nr 2/3, s. 331-351.

${ }_{4}^{4}$ Nazwa ta ma charakter anachroniczny i jest w literaturze przedmiotem wielu dyskusji; zob. S. Nordal, Icelandic Culture, Ithaca 1990, s. 76.

5 Zob. J.V. Sigurðsson, Becoming a Scat Land. The Skattgjafir Process Between the Kings of Norway and the Icelanders c. 1250-1300, w: Taxes, Tributes and Tributary Lands in the Making of the Scandinavian Kingdoms in the Middle Ages, red. S. Imsen, Trondheim 2011, s. 115-131.

${ }^{6}$ Przegląd różnych obszarów badawczych nad Pjódveldið zawiera praca A Companion to Old Norse-Icelandic Literature, red. R. McTurk, Oxford 2005. 
społeczno-polityczne znaczenia różnych form redystrybucji i kontroli nad obrotem ważnych gospodarczo dóbr ${ }^{7}$. Celem niniejszego artykułu jest spojrzenie na gospodarkę Pjódveldið w szerszym kontekście społecznym, wykraczającym poza strategie polityczne islandzkich elit. Poddaję w nim analizie ekonomiczną adaptację średniowiecznych Islandczyków do lokalnego środowiska i rekonstruuję zachodzace między nimi relacje gospodarcze na podstawie treści staroislandzkich źródeł narracyjnych ${ }^{8}$, prywatnych zbiorów prawa Wolnej Wspólnoty zwanych Grágás ${ }^{9}$ oraz wyników badań archeologicznych ${ }^{10}$.

\section{Struktura społeczna i relacje pracy}

Nie dysponujemy danymi pozwalającymi na dokładne określenie wielkości populacji Wolnej Wspólnoty. Na podstawie szacunkowej liczby trzynastowiecznych gospodarstw, wyników badań nad produktywnościa średniowiecznych islandzkich pastwisk oraz wstecznej ekstrapolacji danych z nowożytnych cenzusów liczbę członków Pjódveldið określa się zazwyczaj w literaturze na 50-70 tys. osób ${ }^{11}$.

${ }^{7}$ Zob. zwł. J.V. Sigurðsson, Chieftains and Power in the Icelandic Commonwealth, Odense 1999; J. Byock, Viking Age Iceland, London 2001; V. Pálsson, Language of Power. Feasting and Gift-Giving in Medieval Iceland and Its Sagas, Ithaca 2017.

${ }^{8} \mathrm{Na}$ temat średniowiecznych islandzkich źródeł narracyjnych zob. Sagi islandzkie. Zarys dziejów literatury staronordyckiej, red. J. Morawiec, Ł. Neubauer, Warszawa 2015; odnośnie do historycznej wiarygodności tych źródeł zob. W. Gogłoza, Spór o historyczność sag Islandczyków w perspektywie antropologii prawa, w: Ksiega życia i twórczości. Księga pamiatkowa dedykowana Romanowi A. Tokarczykowi, t. 5: Prawo, red. Z. Władek, Lublin 2014, s. 64-89. O ile nie zaznaczono inaczej, wszystkie odwołania do sag dotyczą wersji opublikowanych w serii Íslenzk fornrit, t. 1-35, Reykjavík 1933-2003, w tłumaczeniu autora.

9 Wszystkie odwołania do Grágás dotyczą wydania opublikowanego w Laws of Early Iceland. The Codex Regius of Grágás with Material from Other Manuscripts, red. A. Dennis, P. Foote, R. Perkins, Winnipeg 1980, w tłumaczeniu autora. Dla ułatwienia odnajdywania odpowiednich fragmentów w tekście używam następującego zapisu: liczba rzymska wskazuje na tom, liczba arabska - paragraf, a liczba arabska zapisana w dolnej linii - stronę, na której on się znajduje. Dla przykładu GII $255_{222}$ wskazuje na paragraf 255 opublikowany w t. 2 Grágás na s. 222 . Symbol $\ddagger$ poprzedzajacy numer paragrafu znamionuje dodatek spoza głównego manuskryptu.

${ }_{10}$ Przegląd badań w tym zakresie zawierają m.in. E. Halstad Mcguire, Archaeology in Iceland. Recent Developments, „Scandinavian-Canadian Studies” 16, 2005-2006, s. 10-26; O. Vésteinsson, Archaeology of Economyand Society, w:A Companion..., s. 7-26.

11 Zob. R. Tomasson, A Millennium of Misery. The Demography of the Icelanders, „Population Studies” 31, 1977, nr 3, s. 405-427; P. Urbańczyk, Zdobywcy..., s. 74; J. Byock, dz. cyt., s. 55. 
Ze staroislandzkich źródeł narracyjnych wynika, że trzon średniowiecznego islandzkiego społeczeństwa stanowili gospodarze (bcendr, 1. poj. bóndi). W świetle norm zawartych $\mathrm{w}$ zachowanych zbiorach prawa Wolnej Wspólnoty, by móc zaliczać się do tego grona, Islandczyk ${ }^{12}$ musiał rozporządzać własnym lub dzierżawionym gospodarstwem (bú) oraz chować zwierzęta mleczne $\left(G I 8_{132}\right)$. Jeśli wartość majątku, jakim rozporządzał bóndi była co najmniej równa prawnie określonemu minimum, ustalonemu na poziomie ,jednej wolnej od obciążeń krowy na każdego domownika lub jej równowartości, bądź też jednej sieci lub łodzi [na domownika - W.G.] i wszystkiego innego, bez czego gospodarstwo nie może się obejść" (GI 89 150 ), uznawany był on przez prawo za gospodarza zdolnego do ponoszenia kosztów udziału w wiecach publicznych (tj. uiszczania opłaty wiecowej zwanej pingfararkaup).

Pingfararkaupsboendr (dosł. „gospodarze płacacy opłatę wiecowa”) mieli prawo do towarzyszenia wybranemu przez siebie wodzowi w wyprawach na Zgromadzenie Powszechne, zasiadania w składach orzekających sądów wiecowych (binadómar), a także udziału w zarządzaniu wspólnotami sassiedzkimi (hreppar) ${ }^{13}$. Jednocześnie ich status majątkowy uniemożliwiał im korzystanie z pomocy dla potrzebujących, świadczonej w ramach rzeczonych wspólnot, a także nakładał na nich obowiązek udzielania wiktu i opierunku tzw. osobom zależnym (ómagar, zob. niżej).

$\mathrm{Z}$ informacji zawartych w Íslendingabók, staroislandzkiej kronice uznawanej za jedno z najbardziej wiarygodnych źródeł na temat Pjódveldi ${ }^{14}$, wynika, że z końcem XI w. do grona pingfararkaupsbondr należało 4560 gospodarzy ${ }^{15}$. Rzeczona kronika nie zawiera informacji pozwalających ustalić procent, jaki stanowili oni pośród ogółu bcendr, jednak zdaniem współczesnych badaczy w całym interesujaccym nas okresie liczba farm na Islandii nigdy nie przekroczyła 6 tys. ${ }^{16}$ Stosunkowo wysoki udział pingfararkaupsbeendr $\mathrm{w}$ grupie islandzkich gospodarzy nie powinien być jednak odczytywany jako sugestia, że boendr stanowili

${ }^{12} \mathrm{O}$ statusie islandzkich kobiet zob. W. Gogłoza, The Social Status of Women in the Old Icelandic Laws, w: Grettir's Little Sword. Constructing Masculinity in Old Norse Society, red. R. Gogosz, T. Zielińska, Rzeszów (w druku).

${ }_{13}$ Zob. G. Karlsson, Social Institutions, w: A Companion..., s. 503-517.

${ }^{14} \mathrm{Na}$ temat tej kroniki, jej autora i kwestii jej historycznej wiarygodności zob. R. Rutkowski, „A ja nazywam sie Ari”. O najstarszej kronice islandzkiej i jej autorze, w: Autor $i$ jego dzieło w wiekach średnich, red. A. Laskowska, M. Sas, Warszawa 2014, s. $63-76$.

15 Íslendingabók and Kristnisaga. The Book of Icelanders, and the Story of the Conversion, red. S. Grønlie, London 2006, s. 12.

16 J.V. Sigurdsson, Iceland, w: The Viking World, red. S. Brink, N. Price, London 2008 , s. 572. 
względnie egalitarną klasę społeczna, zarówno bowiem krytyczna analiza materiałów źródłowych, jak i wyniki badań archeologicznych dowodza, że islandzkie gospodarstwa były istotnie zróżnicowane pod względem majątkowym ${ }^{17}$.

Poziom stratyfikacji islandzkich gospodarzy uwidaczniaja zwłaszcza badania nad wczesnymi farmami. Odkryte na Islandii długie domy z okresu wikińskiego znacząco różnią się zarówno pod względem powierzchni użytkowej, wielkości głównego pomieszczenia, jak i liczby znalezionych $\mathrm{w}$ nich dóbr prestiżowych. Rozmiary tych konstrukcji wahają się od ok. $40 \mathrm{~m}^{2}$, przez $80 \mathrm{~m}^{2}$, aż do znacznie przekraczających $100 \mathrm{~m}^{2}$, z jednym liczacym ponad $276 \mathrm{~m}^{2}$ (farma Hofstaðir w regionie Mývatnssveit) ${ }^{18}$. Budowle te różnią się także atrakcyjnością ich lokalizacji oraz dostępem do zasobów naturalnych. Największe i najlepiej usytuowane niemal na pewno należały do szczególnie prominentnych gospodarzy, w tym zwłaszcza lokalnych wodzów. Ekonomicznym fundamentem prestiżowej pozycji tych ostatnich były bardzo rozległe, dobrze usytuowane gospodarstwa, którym już w okresie zasiedlenia mogły podlegać liczne zależne farmy dzierżawne ${ }^{19}$.

$\mathrm{O}$ ile pingfararkaupsbcendr stanowili najzamożniejszą grupę w społeczeństwie Pjódveldið, o tyle najliczniejszą tworzyli tzw. domownicy (griðmenn, r.ż. griðkonur). Każda osoba, która nie zaliczała się do grona bœendr, musiała posiadać domicyl w jednym z zarządzanych przez nich gospodarstw $\left(\right.$ GI $\left.78_{125-128}\right)$. Małoletnie dzieci pozostawały zazwyczaj pod opieką rodziców i mieszkały wraz z nimi. Osobom, które z powodu wieku, stanu zdrowia lub ułomności nie były zdolne do utrzymania się z pracy własnych rąk (ómagar), przysługiwało miejsce w gospodarstwie należącym do ich krewnych, a w przypadku ich braku bądź też niewypłacalności w domostwie innego członka lokalnej wspólnoty, który był w stanie je utrzymać (GII 234 ${ }_{185-187}$ ). Pozostali Islandczycy musieli zapewnić sobie wikt i opierunek we własnym zakresie, zawierając w tym celu umowę z gospodarzem, który zgodził się ich przyjaćc.

Umowy o domicyl zawierano na rok, w terminie tzw. dni przeprowadzki (fardagar). Były to cztery kolejne dni rozpoczynające się

${ }_{17}$ O. Vésteinsson, A Divided Society. Peasants and the Aristocracy in Medieval Iceland, „Viking and Medieval Scandinavia” 3, 2007, s. 117-137; S. Jakobsson, From Reciprocity to Manorialism. On the Peasant Mode of Production in Medieval Iceland, „Scandinavian Journal of History” 38, 2013, nr 3, s. 273-295.

${ }_{18}$ D. Zori, From Viking Chiefdoms to Medieval State in Iceland, Los Angeles 2010, mps rozprawy doktorskiej, s. 430.

${ }_{19}$ O. Vésteinsson, Patterns of Settlement in Iceland. A Study in Pre-History, „Saga Book" 25, 1998, s. 1-29. 
w czwartek wypadający między 21 a 27 maja $\left(G I 78_{125-126}\right)$. W trakcie ich trwania każda osoba niepozostająca pod opieka krewnych lub innego gospodarza prawnie zobowiązanego do ich utrzymania musiała odnowić zawartą rok wcześniej umowę bądź też zawrzeć nową z kimś innym. Jeśli najpóźniej z poniedziałkowym rankiem nie dysponowała ona domicylem narażała się na karę grzywny. Ci, którzy będąc w pełni sił, odmawiali znalezienia dla siebie domicylu, a tym samym podjęcia pracy w którymś z gospodarstw, bądź też byli w swym zachowaniu tak uciążliwi, że żaden bóndi nie chciał ich przyjąć (GII 143 $3_{52}$ ), mogli zostać pozwani o włóczęgostwo i skazani na karę pełnej banicji $\left(G I 82_{135}\right)^{20}$.

Griðmenn (1. poj. griðmaðr) podlegali gospodarzowi we wszystkich sprawach dotyczących stosunków domowych, byli przez niego reprezentowani w stosunkach zewnętrznych i musieli wykonywać wszystkie powierzone im zadania mieszczące się $\mathrm{w}$ ramach zwyczajowych obowiazków pracowników rolnych. Zawarte w zachowanych kopiach Grágás normy dotyczące obowiązków pracowniczych griðmenn nie sa jednoznaczne, wydaje się jednak z nich wynikać, że okres ich zatrudnienia był podzielony na dwie części ${ }^{21}$.

Domownik był zobowiązany do oddania się do dyspozycji gospodarza, z którym zawarł umowę o domicyl najpóźniej w dzień wyznaczający połowę lata, tj. niedzielę wypadająca między 13 a 19 lipca $\left(G I 78_{126}\right)$. Do tego czasu griðmaðr mógł swobodnie rozporządzać swoją praca, np. oddając się rybołówstwu. Jeśli jednak stawił się w gospodarstwie wcześniej, to za pracę wykonaną w okresie między dniami przeprowadzki a połową lata należało mu się wynagrodzenie w maksymalnej wysokości 24 łokci samodziału (jedno z głównych płacideł funkcjonujących na Islandii, zob. niżej).

Wraz z początkiem drugiej połowy lata domownik miał bezwzględnie stawić się na farmie gospodarza, u którego zdecydował się zamieszkać. Od tego momentu aż do kolejnych dni przeprowadzki griðmenn pracowali na rzecz podejmujących ich gospodarzy, spędzając owce z pastwisk, szlachtując zwierzęta i nawożąc przydomowe łąki ${ }^{22}$. Za wszystkie

${ }^{20}$ Staroislandzkie prawo przewidywało dwa zasadnicze rodzaje sankcji: grzywny występujące w trzech wysokościach: 3, 6 i 12 marek oraz trzy rodzaje banicji: pełnej banicji bez prawa do opuszczenia kraju, pełnej banicji z prawem do opuszczenia kraju oraz mniejszej banicji, tj. banicji tymczasowej, obowiązującej przez 3 lata, na czas których banita musiał opuścić Islandię $\left(G I 60_{110-111}\right)$.

${ }^{21}$ Por. J. Jóhannesson, Íslendinga Saga. A History of the Old Icelandic Commonwealth, Winnipeg 1974, s. 355-357.

${ }^{22}$ Obowiązkiem kobiet zaliczanych do klasy domowników było przede wszystkim tkanie i przędzenie; J. Jochens, Women in Old Norse Society, Ithaca 1995, s. 141-160. 
te prace otrzymywali wyłącznie wikt i opierunek ${ }^{23}$. Jedynie za wypasanie owiec oraz prace w okresie między tzw. zimowymi nocami (veturncetur) a dniem Wszystkich Świętych, tj. przez ok. 2 tygodnie między połowa października a pierwszym listopada, griðmaðr mógł domagać się dodatkowego wynagrodzenia $\left(G I 78_{126}\right)$.

Obok griðmenn funkcje pracowników najemnych pełnili na Islandii także wyspecjalizowani robotnicy, tacy jak szkutnicy, „,budowniczy wznoszacy budynki z norweskiego drewna, albo mosty nad rzekami lub jeziorami, w których pływają ryby dające się złapać w sieć, a także ci, którzy wznoszą szałasy na [polach wiecowych - W.G.]" $\left(G I 78_{127}\right)$. W przeciwieństwie do domowników pracujacych co do zasady wyłącznie $\mathrm{w}$ zamian za utrzymanie, rzemieślnicy otrzymywali za wykonywane przez nich usługi wynagrodzenie o umownie ustalonej wysokości $\left(G I \$ 31_{205}\right)$, a za dodatkowe prace świadczone na rzecz zatrudniającego ich gospodarza mogli domagać się dniówki $\left(\right.$ GI $\left.78_{127}\right)$.

Zarówno średniowieczne źródła narracyjne, jak i wyniki współczesnych badań archeologicznych odnoszących się do okresu zasiedlenia wskazuja, że w pierwszych dekadach od kolonizacji wyspy istotny udział $\mathrm{w}$ islandzkiej sile roboczej mieli niewolnicy ${ }^{24}$. Ślady funkcjonowania niewolnictwa na Islandii odnajdujemy jeszcze w trzynastowiecznych prywatnych zbiorach prawa, wszelako większość współczesnych badaczy uznaje, że przestało ono odgrywać istotną rolę gospodarczą z końcem ery wikińskiej, kiedy ustał napływ nowych niewolników na wyspę ${ }^{25}$.

\section{Warunki naturalne i wczesne strategie eksploatacji zasobów}

Islandia jest subarktyczną wyspą wulkaniczną leżąca na Grzbiecie Śródatlantyckim u styku dwóch płyt tektonicznych - północnoamerykańskiej i euroazjatyckiej ${ }^{26}$. Jej środek przecina ryft, którego stałemu

${ }^{23}$ Według szacunków P. Jóhannessona roczny koszt utrzymania pracownika w okresie Pjódveldið wahał się między 0,75 a 1 marką srebra; tenże, Die Stellung der freien Arbeiter in Island bis zur Mitte des 16. Jahrhunderts, Reykjavík 1933, s. 211.

${ }^{24}$ O. Vésteinsson, Ethnicity and Class in Settlement-Period Iceland, w: The Viking Age. Ireland and the West, red. J. Sheehan, D. Ó Corráin, Dublin 2010, s. 503-505.

${ }_{25}$ Szerzej na ten temat zob. R. Karras, Slavery and Society in Medieval Scandinavia, New Haven 1988, s. 50-145.

${ }^{26}$ Odnośnie do geografii wyspy oraz jej wpływu na społeczeństwo i gospodarkę Pjódveldid zob. S. Porarinsson, Iceland in the Saga Period. Some Geographical Aspects, w: Priðji Vikingafundur, red. K. Eldjárn, Reykjavík 1958, s. 13-24. 
poszerzaniu się towarzyszą częste trzęsienia ziemi, erupcje wulkanów i ekshalacje fumaroli. Mimo że jej powierzchnia przekracza 100 tys. km², jedynie ok. 20\% terenów - głównie obszarów nadbrzeżnych i dolin rzecznych - nadaje się do zamieszkania. Wnętrze wyspy stanowi trudno dostępna kamienno-piaskowa pustynia, poprzecinana kilkunastoma lodowcami o łącznej powierzchni 11 tys. $\mathrm{km}^{2}$ oraz bezkresnymi polami zaschniętej lawy, będącej śladem aktywności przeszło 120 wulkanów, z których ok. 30 nadal jest czynnych i które od czasów zasiedlenia wybuchły prawie dwieście razy. Na niemalże księżycowy krajobraz wnętrza wyspy wpływa również wysoka średnia elewacja terenu, przekraczająca 700 m n.p.m., i towarzysząca jej uboga roślinność, ograniczająca się zasadniczo do tundry zdominowanej przez mchy i porosty, jedynie okazjonalnie urozmaiconej przez brzozowe lasy.

Toponimia wielu islandzkich nazw geograficznych nie pozostawia watpliwości co do skali wyzwania, jakie dla osadników stanowiło produktywne użytkowanie obejmowanych przez nich terenów ${ }^{27}$. Liczne nazwy rozpoczynające się od kald- (,zimno”) - np. Kaldakinn, Kaldidalur, Kaldbakur, itd. - wskazuja na rozczarowanie osadników przybyłych z terenów o cieplejszym klimacie. Z kolei nazwy zawierające w sobie człony reyk-, laug-, eld-, hraun- (odpowiednio „para”, „gorace źródło”, „ogień”, „lawa”) dowodza fascynacji zasadźców przerażająca siła magmy płynącej kilka kilometrów pod ich stopami. Jak jednak słusznie zauważa Bruce E. Gelsinger, gdyby Islandia rzeczywiście stanowiła przedmurze piekieł, których wrota według wierzeń średniowiecznych Islandczyków miały znajdować się u stóp wulkanu Hekla, nigdy nie zostałaby zasiedlona ${ }^{28}$.

$\mathrm{Na}$ przełomie IX i X w., gdy na Islandię przybyła największa fala osadnicza, północna Europa znajdowała się w średniowiecznym optimum klimatycznym, przejawiajaccym się stosunkowo wysokimi średnimi rocznymi temperaturami, brakiem kry w zatokach, mniejszym zasięgiem lodowców, a przez to gęstszą i bujniejszą pokrywą roślinna niż w okresie późnego średniowiecza ${ }^{29}$. Dla łagodzenia chłodnego klimatu większe znaczenie niż w okresach późniejszych miał też opływający południowe wybrzeża Islandii Golfsztrom, wyższa była bowiem temperatura wody niesionej przez niego z Zatoki Meksykańskiej. Z tego

${ }^{27}$ Tamże, s. 20-21.

${ }_{28}$ B.E. Gelsinger, The Icelandic Enterprise. Commerce and Economy in the Middle Ages, Columbia 1981, s. 6.

${ }^{29}$ W. Patterson, K. Dietrich, C. Holmden, J. Andrews, Two Millennia of North Atlantic Seasonality and Implications for Norse Colonies, „Proceedings of the National Academy of Sciences of the United States of America” 107, 2010, nr 12, s. 5308-5309. 
też względu zazielenione wybrzeża wyspy, obfitujące w liczne kolonie ssaków morskich i ptactwa, rozległe łąki rozciagające się wzdłuż dolin rzecznych oraz zatoki pełne dryfującego drewna musiały się wydawać skandynawskim osadnikom relatywnie bogata kraina ${ }^{30}$.

Osadnicy przybyli na Islandię w okresie wiosenno-letnim szybko się jednak przekonali, że ich przetrwanie w lokalnych warunkach było uzależnione od zgromadzenia odpowiednich zapasów na zimę ${ }^{31}$. Skuteczność podejmowanych przez nich $\mathrm{w}$ tym względzie zabiegów była wszelako determinowana przez czynniki znajdujące się poza ich kontrolą i podlegające krótkoterminowym wahaniom. Jeśli okres wiosenno-letni okazał się być suchy i słoneczny, zapewnienie zwierzętom hodowlanym paszy nie stanowiło istotnego wyzwania. Jeśli jednak lato było deszczowe, a zima dłuższa niż zazwyczaj, Islandczycy musieli się zmagać z katastrofalnymi niekiedy konsekwencjami niedożywienia i potęgowanych przez nie chorób ${ }^{32}$. Z też względu średniowieczna Islandia uznawana jest w literaturze za klasyczny przypadek ekonomii okresowych niedoborów (bad year economics) - gospodarki, w ramach której „sprawy miały się dobrze tylko wtedy, gdy nic nie układało się źle"33.

$\mathrm{Z}$ uwagi na niewielki obszar wyspy nadajacy się do produktywnego zagospodarowania oraz zmienność warunków atmosferycznych strategia przetrwania pierwszych Islandczyków opierała się na możliwie najbardziej ekstensywnej eksploatacji lokalnych zasobów ${ }^{34}$. Doskonała ilustracja różnorodności zabiegów podejmowanych przez osadników celem zapewnienia środków niezbędnych do życia jest fragment Egils saga, poświęcony jednemu z pierwszych islandzkich zasadźców Skalla-Grímurowi Kveld-Úlfssonnowi.

Skalla-Grímur był niesłychanie dzielny i obrotny; [...] zbierał i gromadził, polował i łowił wszędzie, gdzie tylko sposobność się nadarzyła, by wyżywić

${ }^{30}$ O. Vésteinsson, The Archeology of Landnám..., s. 165.

${ }^{31}$ Zob. np. zachowane w Księdze zasiedlenia, średniowiecznej kronice majacej stanowić zapis przebiegu kolonizacji Islandii, przekazy na temat jednego z pierwszych zasadźców Flókiego Vilgerðarsona, zmuszonego do powrotu do Norwegii, po tym jak przywiezione przez niego zwierzęta hodowlane pomarły z głodu; Landnámabók. The Book of Settlements, red. H. Pálsson, P. Edwards, Manitoba 1972, s. 18.

${ }^{32}$ P. Eggertsson, Sources of Risk, Institutions for Survival, and a Game against Nature in Premodern Iceland, „Explorations in Economic History” 35, 1998, s. 1-30.

33 J. Byock, dz. cyt., s. 57 (tłum. W.G.).

${ }_{34}$ T. McGovern, S. Perdikaris, Á. Einarsson, J. Sidell, Coastal Connections, Local Fishing, and Sustainable Egg Harvesting. Patterns of Viking Age Inland Wild Resource Use in Mývatn District, Northern Iceland, „Environmental Archaeology” 11, 2006, nr 2, s. 187-205. 
swoich ludzi. Z początku bowiem mieli za mało bydła w stosunku do gromady ludu, która tu przybyła. Bydło, które mieli ze soba, puścili na pastwisko przez okragły rok [...] i musiało samo szukać sobie pożywienia w lasach. Skalla-Grímur był wielkim budowniczym statków, a wspaniałego budulca, drzewa naniesionego przez fale, nie brakowało na całym wybrzeżu. Na Alptanesie kazał także pobudować dom i podwórze i zaprowadził tam gospodarstwo; stamtąd to wychodziły wyprawy na połów ryb na morzu i na polowania na foki, i na zbieranie jaj. W owym czasie było nieprzebrane mnóstwo wszystkiego, tak samo jak drzewa napędzonego przez fale, trzeba było tylko zabierać i wieźć do domu. Wieloryby podpływały także bardzo często do wybrzeża i kto chciał, mógł je strzelać. Wszystkie zwierzęta leżały spokojnie na miejscach połowu, bo nie znały człowieka. Trzecia włość miał Skalla-Grímur na zachodnim wybrzeżu Myrar. Tam położenie było jeszcze korzystniejsze i jeszcze więcej sposobności wyławiania rzeczy, które morze wyrzucało. [...] Skalla-Grímur miał także swoich ludzi przy rzekach, gdzie było pełno łososi. [...] Gdy inwentarz Skalla-Grímura zaczął się mnożyć, ciagnęły te stada w porze letniej daleko w góry. Skalla-Grímur zauważył, że bydło, które się pasło na halach górskich, było o wiele lepsze i tłustsze, spostrzegł również, że owce same ściągały na zimę do dolin górskich, choć ich się tam nie spędzało. Później założył Skalla-Grímur gospodarstwo w wysokich górach i tam żyli i pracowali ludzie, którzy doglądali inwentarza na halach. [...] W ten sposób - jak powiadali - majątek Skalla-Grímura stał na wielu nogach (Saga o Egilu, rozdz. 29, tłum. A. Załuska-Stromberg).

Podobne relacje na temat działań podejmowanych przez zasadźców znajdujemy także w innych staroislandzkich źródłach narracyjnych, co sugeruje, że strategia dyferencjacji eksploatowanych zasobów była powszechnie wykorzystywana przez pierwszych osadników ${ }^{35}$. Wiele dowodów jej stosowania przynoszą nam też badania zooarcheologiczne. Szczątki zwierzęce odkryte $\mathrm{w}$ depozytach $\mathrm{z}$ okresu zasiedlenia Islandii wskazuja, że kolonizatorzy przywié́li ze sobą na wyspę zwierzęta hodowlane, w tym bydło, owce, kozy i świnie. W początkowym okresie bardzo duży udział $\mathrm{w}$ archeofaunie maja ostatnie dwa gatunki, co może wynikać z faktu, że w przeciwieństwie do bydła były one w stanie samodzielnie żerować $\mathrm{w}$ lasach, pokrywajacych wówczas znaczna część powierzchni wyspy. Wraz jednak z postępującym procesem przekształcania terenów leśnych na łąki i pastwiska ich liczba zaczyna spadać na rzecz bydła i owiec. W konsekwencji tych zmian w XI w. proporcje zwierząt hodowlanych ulegaja odwróceniu - świnie niemal całkowicie zanikaja, liczba bydła stabilizuje się w relacji do pozostałych

${ }^{35}$ P. Urbańczyk, Zdobywcy..., s. 75. 
gatunków, a wśród zwierząt kozłowatych dominująca pozycję zaczynają odgrywać owce ${ }^{36}$.

Przeprowadzone analizy islandzkich depozytów zwierzęcych potwierdzają również średniowieczne przekazy głoszące, że w początkowym okresie zasiedlenia liczba sprowadzonych na wyspę zwierząt hodowlanych była zbyt mała w stosunku do wielkości populacji osadników, przez co musieli oni podejmować wiele starań w celu zdobycia dodatkowego pożywienia dzięki polowaniom, rybołówstwu i zbieractwu ${ }^{37}$. Podczas gdy w archeofaunie odkrytej na terenie norweskich farm z tego okresu zdecydowanie dominująca rolę odgrywają szczątki udomowionych ssaków, na Islandii większość najstarszych depozytów zwierzęcych stanowią szczątki gatunków wolno żyjących. W południowej Islandii sa to przede wszystkim różne gatunki dzikiego ptactwa, stanowiące nawet do $75 \%$ ogółu archeofauny, na północy kraju zaś ryby słodkowodne. Ponadto w ramach badań zooarcheologicznych zidentyfikowano szczątki morsów, fok, morświnów, wielorybów i kilku gatunków ryb morskich ${ }^{38}$.

O ile jednak średniowieczne przekazy odnoszace się do konsumpcji i hodowli prowadzonej przez pierwszych osadników wydają się mieć potwierdzenie w wynikach badań archeologicznych, o tyle te odnoszące się do sposobu dystrybucji produktów będących efektem eksploatacji lokalnych zasobów moga budzić pewne wątpliwości. Z przytaczanego wyżej fragmentu Egils saga wynika bowiem, że pozyskiwanie różnorodnych zasobów miało charakter planowy i odbywało się w ramach jednego, dużego gospodarstwa, któremu podlegało wiele wyspecjalizowanych jednostek pomocniczych. Taka sytuacja mogła mieć miejsce na Islandii, nie musiała jednak stanowić normy. Gdyby bowiem ten sposób eksploatacji zasobów miał charakter powszechny znaczna część najstarszych zabudowań powinna mieć charakter odizolowanych chat wykorzystywanych jedynie sezonowo, tymczasem badania w najlepiej poznanym przez archeologów obszarze zasiedlenia, Mývatnssveit w północno-wschodniej Islandii, wskazuja, że nawet najdalej wysunięte, ściśle wyspecjalizowane farmy były zazwyczaj całorocznymi gospodarstwami

${ }_{36}$ T. Mcgovern, O. Vésteinsson, A. Friðriksson i in., Landscapes of Settlement in Northern Iceland. Historical Ecology of Human Impact and Climate Fluctuation on the Millennial Scale, „American Anthropologist” 109, 2007, s. 40.

${ }^{37}$ Tamże, s. 38-43.

38 S. Perdikaris, T. McGovern, Cod Fish, Walrus, and Chieftains. Economic Intensification in the Norse North Atlantic, w: Seeking a Richer Harvest. The Archaeology of Subsistence Intensification, Innovation, and Change, red. T. Thurston, C. Fisher, Boston 2007, s. 198-199. 
rodzinnymi, użytkowanymi często przez wiele pokoleńn ${ }^{39}$. Większość z nich wydaje się być samodzielna ekonomicznie, co może sugerować, że przetwarzane przez nie zasoby były przedmiotem obrotu, wymiany lub podarunku między niezależnymi farmerami, a nie (re)dystrybucji prowadzonej w obrębie jednego dużego gospodarstwa.

Szczególnie interesującymi wydają się być w tym względzie znaleziska wskazujace na szeroki dostęp pierwszych Islandczyków do ryb morskich, głównie dorszy, duże ilości ich szczątków odkryto bowiem także na terenie farm z czasów osadnictwa, położonych 50 (Granastaðir), 70 (Háls), a nawet $90 \mathrm{~km}$ (Aðalból) w głębi lądu ${ }^{40}$. Podobne znaleziska występuja w różnych, często znacznie od siebie oddalonych regionach kraju, przez co zjawisko to nie ma charakteru lokalnego. O ile wśród szczątków lokalnie pozyskiwanych ryb słodkowodnych archeolodzy znajduja zazwyczaj kompletne szkielety, o tyle szczattki ryb morskich sa zawsze fragmentaryczne, a brakujące części sa w olbrzymiej większości przypadków te same. W morskiej archeofaunie odkrytej na terenie farm leżących w głębi lądu brakuje głowy i górnych partii kręgosłupa. Zdaniem badaczy jest bardzo mało prawdopodobne, by zjawisko to było efektem zróżnicowanej trwałości kości, co sugeruje, że ryby morskie zabijano i oprawiano tuz po ich złowieniu, a w głąb wyspy transportowano produkty już przetworzone. Sposób oprawiania wskazuje, że produktem zabiegów oczyszczających były klipfisk, tj. suszone filety. Proces ich przygotowania trwa wiele miesięcy, co w zasadzie wyklucza, by $\mathrm{w}$ ich produkcję mogli być zaangażowani pracownicy z farm położonych w głębi lądu ${ }^{41}$.

Klipfisk jest bardzo pożywnym, wysokobiałkowym pokarmem, który mógł być przechowywany nawet do 7 lat. Ich długi okres przydatności do spożycia sprawiał też, że mogły być one wykorzystywane nie tylko dla celów konsumpcyjnych, ale także ekonomicznych - akumulacji, redystrybucji, a przy odpowiedniej obróbce, gwarantującej zachowanie zbliżonych rozmiarów, także wymiany w charakterze płacidła. Cechy te moga tłumaczyć fakt rosnacego udziału szczątków ryb morskich w islandzkiej archeofaunie. O ile w X i XI w. sa one jednym $\mathrm{z}$ wielu elementów depozytów zwierzęcych, o tyle w końcu XII w. zaczynają dominować zarówno w archeofaunie farm przybrzeżnych, jak i tych znacznie

39 T. Mcgovern, O. Vésteinsson, A. Friðriksson i in., Landscapes..., s. 35.

${ }^{40}$ S. Perdikaris, T. McGovern, Viking Age Economics and the Origins Of Commercial Cod Fisheries in the North Atlantic, w: Beyond the Catch. Fisheries of the North Atlantic, the North Sea and the Baltic, 900-1850, red. L. Sickling, D. Abreu-Ferreira, Leiden 2008, s. 66-72.

${ }^{41}$ Tamże, s. 75-77. 
oddalonych od morza, w późnym średniowieczu sięgając często nawet $80 \%$ wszystkich szczątków zwierzęcych ${ }^{42}$.

Fakt, że gospodarka Islandii stopniowo przestawiała się z hodowli bydła i owiec na rybołówstwo morskie i przetwórstwo rybne jest dobrze udokumentowany w źródłach, jednak relewantne przekazy łączą go dopiero z rozwojem handlu hanzeatyckiego ${ }^{43}$. Przytaczane wyżej wyniki badań zooarcheologicznych sugeruja jednak, że korzenie tego procesu sięgaja przełomu IX i X w., kiedy część islandzkich osadników dostrzegła potencjał ekonomiczny obrotu rybami morskimi. Nie jest możliwym określenie, czy obrót ten już wówczas miał charakter komercyjny, czy też, co wydaje się bardziej prawdopodobne, początkowo służył innym celom, np. wzmacnianiu pozycji lokalnych wodzów ${ }^{44}$. Niemniej jednak niezaprzeczalne jest, że jeszcze w okresie zasiedlenia powstała rozległa sieć dystrybucyjna, łącząca często bardzo odległe rejony kraju, za pomoca której rozprowadzano wśród mieszkańców farm niemających dostępu do morza znaczne ilości suszonych dorszy, produktu, który w późnym średniowieczu stał się podstawą islandzkiego eksportu ${ }^{45}$.

\section{Gospodarka hodowlana}

Przetrwanie w warunkach subarktycznych wymagało od mieszkańców Islandii znacznej dyferencjacji eksploatowanych zasobów, wraz jednakże z powiększaniem się pogłowia przywiezionych przez zasadźców zwierząt gospodarskich Islandczycy zaczęli coraz wyraźniej zwracać się $\mathrm{ku}$ tradycyjnym nordyckim formom gospodarowania, tj. hodowli bydła i owiec, nie zaniedbując przy tym rybołówstwa, zbieractwa i polowan ${ }^{46}$. Cześć źródeł narracyjnych, jak choćby wcześniej przywoływana Saga o Egilu (rozdz. 29), wskazuje, że osadnicy próbowali także uprawiać rolę, co potwierdzają wyniki badań archeologicznych, paleobotanicznych

${ }^{42}$ S. Perdikaris, T. McGovern, Cod Fish..., s. 199.

${ }^{43}$ G. Marcus, The Norse Traffic With Iceland, „The Economic History Review” 9, 1957, nr 3, s. 409-410.

${ }^{44}$ S. Perdikaris, From Chiefly Provisioning to Commercial Fishery. Long Term Economic Change in Arctic Norway, „World Archaeology” 30, 1999, nr 3, s. 388-402.

45 S. Perdikaris, T. McGovern, Viking Age..., s. 61-90; M. Gardiner, N. Mehler, English and Hanseatic Trading and Fishing Sites in Medieval Iceland. Report on Initial Fieldwork, „Germania” 85, 2007, s. 385-427.

${ }^{46} \mathrm{Na}$ temat tradycyjnej nordyckiej gospodarki zob. T. Amorosi, P. Buckland, K. Edwards i in., They Did Not Live by Grass Alone. The Politics and Paleoecology of Animal Fodder in the North Atlantic Region, „Environmental Archaeology” 1, 1998, s. $41-54$. 
i entomologicznych ${ }^{47}$, jednak uzyskiwane przez nich plony były zbyt małe, by mogły zaspokoić lokalne potrzeby na produkty roślinne, w tym zwłaszcza zboża, przez całe wieki stanowiące jedne z najbardziej poszukiwanych towarów importowych ${ }^{48}$. Z uwagi na bardzo słaba jakość lokalnych gleb, które za sprawą drobnoziarnistości i wysokiej mineralizacji sa szczególnie podatne na erozję eoliczna, prymitywne rolnictwo przynosiło $\mathrm{w}$ islandzkich warunkach znacznie niższe zwroty nakładów niż chów zwierząt gospodarskich ${ }^{49}$.

Podstawowa jednostka organizacyjna średniowiecznej islandzkiej gospodarki była farma (bcer). Pod pojęciem tym rozumiano wyraźnie wyodrębnione użytki rolne wraz z wszystkimi wzniesionymi na ich terenie budynkami. Sercem typowego islandzkiego gospodarstwa była „wewnętrzna łąka” (tún lub töðuvöllr), otoczona wysokim na ok. $180 \mathrm{~cm}$ ogrodzeniem. Szczególne znaczenie tej łakki wynikało z faktu, że zazwyczaj była ona jedynym kultywowanym użytkiem rolnym. Pozyskiwane $\mathrm{z}$ niej wysokiej jakości siano przechowywano w przylegającej do wewnętrznej strony ogrodzenia prowizorycznej stodole i przeznaczano wyłącznie dla mlecznych krów. Pozostałe zwierzęta gospodarcze karmiono paszą pozyskiwaną $\mathrm{z}$ nienawożonych łąk zewnętrznych, zazwyczaj znacznie oddalonych od gospodarstwa głównego.

Wyniki badań zooarcheologicznych wskazuja, że głównymi zwierzętami hodowanymi przez Islandczyków były konie, bydło i owce ${ }^{50}$. Sporadycznie w ramach najstarszej islandzkiej archeofauny można odnaleźć też kości udomowionych królików ${ }^{51}$, a zachowane zbiory prawa zawieraja informacje na temat znakowania ergo chowu ptactwa $\left(\right.$ GII 208 ${ }_{139}$ ). W'sród krętorogich zdecydowanie łatwiejszymi w utrzymaniu były owce i to ich hodowla stanowiła podstawę utrzymania dla przeciętnego islandzkiego gospodarstwa domowego. Dzięki grubej i gęstej okrywie włosowej były one w stanie przez większość roku samodzielnie żerować na pastwiskach, przez co ich właściciele/dzierżawcy mieli mniejsze zapotrzebowanie na dostęp do łąk niż hodowcy bydła i poświęcali mniej czasu na pracochłonne sianokosy. Jednocześnie ich hodowla dostarczała wielu dóbr

${ }^{47}$ P. Urbańczyk, Zdobywcy..., s. 70.

${ }^{48}$ Ziemniaki, które z uwagi na niewielkie wymagania upraw i wysoka wartość odżywczą mogłyby stanowić istotne uzupełnienie diety, nie były wówczas Europejczykom znane. Na Islandii zaczęto je uprawiać dopiero w 1759 r.; K. Gjerset, History of Iceland, New York 1925, s. 74.

${ }^{49}$ I. Simpson, W. Adderley, G. Guðmundsson i in., Soil Limitations to Agrarian Land Production in Premodern Iceland, „Human Ecology” 30, 2002, nr 4, s. 423-443.

50 T. Mcgovern, O. Vésteinsson, A. Friðriksson i in., Landscapes..., s. 40-41.

${ }^{51}$ D. Zori, dz. cyt., s. 382. 
podlegających konsumpcji, akumulacji i obrotowi. Szczególnie cennym produktem owczym była wełna wykorzystywana do szycia ubrań, żagli i namiotów oraz tkania samodziału zwanego vaðmál (dosł. „miara tkaniny"), stanowiącego główny produkt eksportowy Islandii i funkcjonującego lokalnie w charakterze płacidła. Ponadto dostarczały one wielu produktów spożywczych, łoju wykorzystywanego jako paliwo do lamp oraz skór przerabianych m.in. na pergamin.

$\mathrm{W}$ przeciwieństwie do owiec, dobrze radzących sobie $\mathrm{w}$ islandzkim klimacie, bydło w okresie zimowym musiało być trzymane pod dachem i karmione sianem, którego pozyskiwanie i przechowywanie w deszczowej Islandii nie było łatwe. $Z$ tego też względu jesienią spędzano je z powrotem do przydomowych obór, poddawano selekcji, a następnie najsłabsze z nich szlachtowano, chcac tym samym zapewnić odpowiednią ilość paszy dla pozostałej części stada. Pomimo powyższych problemów wykopaliska przeprowadzone na terenie islandzkich gospodarstw z okresu wikińskiego wskazuja, że charakteryzowały się one stosunkowo wysokim udziałem bydła wśród zwierząt gospodarskich ${ }^{52}$, co najprawdopodobniej było powodowane czynnikami kulturowymi (w średniowiecznych społeczeństwach nordyckich bydło uznawano za wskaźnik zamożności) ${ }^{53}$. Hodowla bydła dostarczała ponadto spożywanego na co dzień nabiału, skór, z których wytwarzano elementy ubioru oraz welin, rogów wykorzystywanych do produkcji narzędzi i ozdób, a także pęcherzy płodowych, które rozciagano na ramach okiennych zamiast szyb.

W okresie letnim większość zwierząt gospodarskich wypasano na górskich pastwiskach. Jakkolwiek w źródłach określa się je mianem „wspólnotowych" (afrétt), analiza staroislandzkich zbiorów prawa nie pozostawia wątpliwości, że były one własnościa prywatna, poddaną jednak ścisłym regulacjom określającym zasady ich użytkowania, przez co mogą być one postrzegane jako wspólne zasoby wielu właścicieli (wariant common pool resources) ${ }^{54}$. Z norm zawartych w zachowanych kopiach Grágás wynika, że pastwisko uznawano za wspólnotowe, jeśli miało dwóch lub więcej właścicieli $\left(G I I 205_{138}\right)$. W okresie letnim (z wyłączeniem

${ }^{52}$ Badania zooarcheologiczne wykazują przy tym dwa różne „profile produkcyjne” bydła. W mniej zamożnych gospodarstwach było ono hodowane przede wszystkim dla mleka, w bogatych zaś dla znacznie bardziej kosztownego mięsa; C. Keller, S. Perdikaris, The Northern Frontier - North Atlantic Farming During the Viking and Middle Ages, w: Agricultural and Pastoral Landscapes in Pre-Industrial Society, red. F. Retamero, I. Schjellerup, A. Davies, Oxford 2016, s. 45.

${ }^{53}$ D. Zori, dz. cyt., s. 382-383.

${ }^{54}$ E. Ostrom, Dysponowanie wspólnymi zasobami, tłum. Z. Wiankowska-Ładyka, Warszawa 2013. 
dwóch tygodni wypadajacych między początkiem ostatniego tygodnia maja a końcem pierwszego tygodnia czerwca, kiedy pastwiska miały leżeć odłogiem celem regeneracji pokrywy roślinnej) korzystać z nich mogły wyłącznie osoby dysponujacce odpowiednim tytułem prawnym oraz ewentualnie osoby przez nie uprawnione, o ile uzyskały one zgodę wszystkich pozostałych właścicieli. Przez pozostały okres roku prawem do wypasania na nich zwierząt dysponowali też gospodarze użytkujący sasiadujące z nimi użytki zielone. Nieuprawnione wypasanie zwierząt zagrożone było grzywna, a prawem do jej dochodzenia dysponowali wszyscy właściciele, którzy nie wyrazili na nie zgody (GII 201 ${ }_{131}$ ).

Celem zapobiegania nadmiernej eksploatacji pastwisk staroislandzkie prawo zakazywało ich koszenia $\left(G I I 201_{131}\right.$ ) oraz przewidywało specjalny sposób określania liczby zwierząt, które poszczególni właściciele lub upoważnione przez nie osoby mogły wyprowadzać na wypas $\left(\right.$ GII 202 ${ }_{133}$ ). Przed czwartkiem wypadajacym między 4 a 10 czerwca pięciu właścicieli ziemskich, których grunty znajdowały się najbliżej danego pastwiska i którzy sami nie posiadali w nim udziału, ani nie byli blisko spokrewnieni z jego uprawnionymi użytkownikami, dokonywało na wniosek jednego $\mathrm{z}$ tych ostatnich obliczenia przydziału przynależnego każdemu z gospodarzy wypasających na nim swe zwierzęta. Indywidualne udziały miały być ustalone w taki sposób, by wypasane „zwierzęta nie stały się grubsze nawet jeśli byłoby ich mniej, a przy tym by pastwisko było maksymalnie wykorzystane" (GII $201_{133}$ ). Wysokość przydziału podawano w krowach i ich ekwiwalentach: jedna krowa była równoważna jednemu wołowi co najmniej trzyletniemu, jednemu dwuletniemu lub młodszemu koniowi, dwom wołom nie starszym niż dwuletnie lub dwudziestu owcom $\left(\right.$ GII $180_{109}$ ). Jeśli przydział przyznany użytkownikowi był wyższy niż liczba posiadanych przez niego zwierząt, mógł on w ramach swojego udziału wypasać zwierzęta należące do osób trzecich. Przekroczenie przydziału było zagrożone karą grzywny, a sądem właściwym do rozpoznania wszystkich sporów związanych z użytkowaniem wspólnotowych pastwisk był tzw. afréttardómr (dosł. „sąd do spraw pastwisk”, GII 202 ${ }_{134-136}$ ).

Z końcem lata zwierzęta miały zostać spędzone z pastwisk i rozdzielone między właściwych gospodarzy. Celem umożliwienia ich segregacji prawo nakładało na właścicieli obowiazek odpowiedniego oznakowania wszystkich należących do nich zwierząt gospodarskich z wyjątkiem koni (GII 225 $\left.{ }_{168-174}\right)$. Znaki identyfikacyjne należało nanieść najpóźniej z upływem ósmego tygodnia lata i zazwyczaj zajmowali się tym pasterze. Niewywiązanie się z tego obowiązku było zagrożone kara grzywny. Bydło, owce i świnie znakowano na uszach, ptaki na nogach. Znaki 
podlegały dziedziczeniu na zasadach ogólnych oraz ograniczonemu obrotowi. Osoba, która dopiero zakładała gospodarstwo, mogła za porozumieniem przejać znak od kogoś, kto zdecydował się zaprzestać gospodarowania, bądź też stworzyć zupełnie nowe oznaczenie, ogłaszając ten fakt podczas właściwego dla niej wiecu lokalnego $\left(\text { GII } 225_{172}\right)^{55}$. Podobnie każdy nowy członek wspólnoty sąsiedzkiej ${ }^{56}$ był zobowiązany do publicznego ogłoszenia swojego znaku podczas pierwszego jej spotkania, w którym uczestniczył, gdyby zaś okazał się on identyczny z wcześniej wykorzystywanym przez któregoś z jej członków, musiał go zmienić na inny $\left(\right.$ GII $\left.225_{172}\right)$. Jeśli nieoznakowane zwierzę, inne niż jagnię, wkroczyło na teren należący do osoby trzeciej, miała ona prawo oznakować jej jako własne po uprzednim okazaniu go pięciu sasiadom. Potajemne oznakowanie cudzego zwierzęcia własnymi znakami traktowano jako kradzież, czyn zagrożony kara pełnej banicji (GII 225 $\left.{ }_{169}\right)$.

\section{Wewnętrzna wymiana gospodarcza}

Staroislandzkie źródła narracyjne przedstawiają farmy prominentnych boendr jako samowystarczalne podmioty gospodarcze, które przy sprzyjających warunkach atmosferycznych były zdolne do samodzielnego zaspokajania bieżących potrzeb ich właścicieli i domowników. Przekazy te, w połączeniu ze stosunkowo niewielkim stopniem zróżnicowania zasobów dostępnych w różnych regionach wyspy oraz trudnymi warunkami transportu, były w przeszłości powszechnie interpretowane przez badaczy jako sugerujace, że wewnętrzny obrót gospodarczy odbywał się na Islandii na niewielką skalę i był skoncentrowany wokół dóbr luksusowych oraz wyrobów rzemieślniczych ${ }^{57}$. Obecnie w literaturze przeważaja jednak opinie, że zakres wymiany handlowej prowadzonej przez

${ }^{55}$ Poza Zgromadzeniem Powszechnym w skład struktury wiecowej Pjódveldið wchodziły jeszcze wiece lokalne (héraðsping), pełniące przede wszystkim funkcje sądowo-informacyjne. Spotykały się one dwa razy do roku, wiosną i jesienia, i w świetle treści staroislandzkich źródeł każdemu z nich miało przewodniczyć po trzech lokalnych wodzów. Ponadto obowiązkowo uczestniczyli w nich wszyscy stowarzyszeni z nimi wolni gospodarze zdolni do ponoszenia opłat wiecowych (GI 56-59 ${ }_{98-109}$, GI $\left.61_{111-112}\right)$.

56 W okresie Pjódveldið wspólnotę sąsiedzką tworzyła grupa co najmniej 20 sassiadujacych ze soba bingfararkaupsboendr $\left(G I I 234_{185}\right)$. Głównym zadaniem wspólnot miało być udzielanie pomocy gospodarzom zagrożonym niewypłacalnością ( $G I I \quad 234_{187-191}$ ) oraz administrowanie systemem ubezpieczeń wzajemnych przed skutkami pożarów i pomoru zwierząt gospodarskich $\left(G I I \$ 420_{352-353}\right)$.

${ }^{57}$ K. Gjerset, dz. cyt., s. 79. 
średniowiecznych Islandczyków był znacznie większy, niż wynikałoby to z treści staroislandzkich sag i że obejmował on również obrót dobrami konsumpcyjnymi ${ }^{58}$.

Z przywoływanych wyżej wyników badań archeologicznych widać, że jeszcze w okresie wikińskim Islandczycy na szeroką skalę obracali rybami morskimi. Nie jesteśmy w stanie określić, kiedy nastapiła na Islandii komodytyzacja zasobów połowowych, jednak zdaniem Sophi Perdikaris i Thomasa McGoverna stało się to najpóźniej z końcem XII w. ${ }^{59}$ Jej ślady odnajdujemy w zachowanych źródłach narracyjnych ${ }^{60}$. Transakcję kupna dużej ilości suszonych ryb odnotowuje spisana w XIII, a rozgrywająca się w XI w. Grettis saga (rozdz. 42), jednak dotyczaccy jej fragment może mieć charakter anachroniczny. W budzacej mniej wątpliwości co do wiarygodności utrwalonych w niej przekazów Guðmundar saga dýra ukazana została postać żyjaceego na przełomie XII i XIII w. Porvalda z Siglunes, którego zwyczajem było „załadowywanie łodzi rybami i transportowanie ich w głąb fiordu, gdzie mogły być one sprzedane gospodarzom żyjącym dalej [od wody - W.G.]".

W świetle na poły satyrycznej Bandamanna saga tego rodzaju handel mógł być bardzo intratny. W ten sposób swój majątek, dorównujący majątkom najpotężniejszych islandzkich wodzów, miał bowiem zdobyć jeden z głównych bohaterów tej sagi, Oddr Ófeigsson. Nie jest możliwe obecnie określenie, na ile postać Odda utrwalona w tej sadze (jak i Odds páttr Ófeigssonar oraz Hemings páttr Áslákssonar, gdzie pojawia się on jako bogaty kupiec przyjmowany z honorami przez norweskiego króla Haralda III Harðrádi) odpowiada rzeczywistej osobie, żyjącej na Islandii ok. połowy XI w. Niemniej jednak pochodzenie przypisywanego mu przez sögumenn (redaktorów zachowanych wersji sag) majątku zdaje się wskazywać, że w XIII w., gdy utrwalono na piśmie opowieści o nim, lokalny handel rybami musiał być już na tyle rozwinięty na Islandii, by możliwość osiagania na nim wielkich zysków nie wzbudzała zdziwienia u współczesnych odbiorców.

Okazjonalnie w staroislandzkich źródłach narracyjnych napotykamy też na postaci domokrążców w rodzaju Kaupa-Héđina (Njáls saga, rozdz. 23), utrzymujących się z obwoźnej sprzedaży całej gamy towarów cieszących się lokalnym popytem ${ }^{61}$. Także w tym przypadku działalność ta przedstawiana jest jako intratna. Szczególnie znamiennym w tym względzie jest

${ }^{58}$ S. Perdikaris, T. McGovern, Viking Age..., s. 66-72.

${ }^{59}$ Ciż, Cod Fish..., s. 200-201.

${ }^{60}$ W. Miller, Bloodtaking and Peacemaking. Feud, Law, and Society in Saga Iceland, Chicago 1990, s. 79-80.

${ }^{61}$ Tamże, s. 79. 
przykład Pórira zwanego Kurą. Według tradycji spisanej w poświęconej mu sadze miał on żyć z handlu dobrami gospodarskimi, a swój przydomek zawdzięczać jednej szczególnie dla niego udanej wyprawie handlowej na północ kraju, w ramach której udało mu się sprzedać z dużym zyskiem znaczną ilość kur niosek. Zarobione w ten sposób środki miał następnie przeznaczyć na zakup dobrze prosperującego gospodarstwa, za sprawa którego zyskał status jednego z najbogatszych lokalnych gospodarzy (Hcensa-Póris saga, rozdz. 1).

Jakkolwiek handel obwoźny mógł przynosić przedsiębiorczym jednostkom wysokie zyski, liczba zaangażowanych weń osób była na Islandii niemal na pewno bardzo mała i miały one bardzo niski status wśród lokalnych gospodarzy ${ }^{62}$. Świadczą o tym przede wszystkim bardzo negatywne opisy, jakie zazwyczaj towarzyszyły tego rodzaju postaciom w źródłach narracyjnych. Dla przykładu o przywoływanym wyżej Hænsa-Pórir sagamaðr napisał, że „choć dorobił się on wielkiego majątku, wciąż pozostawał mało lubianym, albowiem było mało prawdopodobnym, by żyła mniej odrażająca kreatura, niż ta, za jaka [on - W.G.] uchodził" (Hcensa-Póris saga, rozdz. 1).

Niewielka liczba islandzkich domokrążców oraz ich niski status społeczny nie powinien być jednak odczytywany jako dowód na niewielka skalę wewnętrznej wymiany handlowej. Treść staroislandzkich źródeł narracyjnych wskazuje bowiem, że obrót lokalnie dostępnymi dobrami odbywał się pomiędzy niepozostającymi ze sobą w długotrwałych relacjach ekonomicznych stronami przede wszystkim w ramach regularnie odbywających się w wielu regionach kraju targowisk, dla których sprzedaż obwoźna stanowiła jedynie uzupełnienie ${ }^{63}$. Większość z owych targów organizowano na terenie i przy okazji spotkań wieców lokalnych ${ }^{64}$. Normy zawarte w Grágás sugeruja że obok vaðmál szczególnie często obracano podczas ich trwania zwierzętami gospodarskimi oraz ich skórami, żywnościa, w tym zwłaszcza nabiałem oraz rybami, a także wyrobami z żelaza (GII $\left.246_{207-210}\right)$.

Z treści zachowanych staroislandzkich źródeł wynika również, że duże targowisko odbywało się w ramach Zgromadzenia Powszechnego, a wśród jego licznych uczestników pokaźną grupę obok krajowych i zagranicznych kupców stanowili także rzemieślnicy, w tym piwowarzy, garbarze, szewcy i miecznicy ${ }^{65}$. Popularne jarmarki organizowane były

${ }^{62}$ E. Sveinsson, The Age of the Sturlungs. Icelandic Civilization in the $13^{\text {th }}$ Century, Ithaca 1953, s. 47.

${ }_{63}$ B.E. Gelsinger, dz. cyt., s. 32.

${ }^{64}$ J. Jóhannesson, dz. cyt., s. 81.

65 S. Nordal, dz. cyt., s. 100. 
również kilkukrotnie w roku przy kościołach katedralnych w Skálholt i Hólar oraz na terenie islandzkich opactw. W okresie wiosenno-letnim targi odbywały się też przy ruchliwych przystaniach i zatokach ${ }^{66}$. Szczególnie licznie uczęszczanymi były te odbywające się na targowiskach w Gásir, w którym, jak wykazują badania archeologiczne, handel prowadzony był już w X w. ${ }^{67}$, oraz Hvítá i Eyrarbakki na południu kraju, gdzie często przybijały statki zagranicznych kupców ${ }^{68}$.

Największy udział w wewnętrznym obrocie gospodarczym na Islandii wydają się mieć wszelako transfery dokonywane w ramach umów dzierżawy oraz pożyczek na procent. Tego rodzaju transakcje sa stosunkowo często odnotowywane w źródłach narracyjnych, zwłaszcza tych dotyczących XII i XIII w. ${ }^{69}$, jednakże o ich szczególnym znaczeniu gospodarczym świadczy przede wszystkim uwaga poświęcona im przez redaktorów zachowanych zbiorów staroislandzkiego prawa (GII 221-226 155-175. . Zgodnie z normami zawartymi w Grágás dzierżawie (leiga) na Islandii podlegały zarówno nieruchomości (GII 219 ${ }_{150-151}$ ), jak i zwierzęta gospodarskie (GII $224_{166-168}$ ). Wszelkie umowy dzierżawne (leigumáli) zawierano na rok, a początek i koniec tego okresu wyznaczały dni przeprowadzki.

Gospodarzowi dzierżawiącemu grunty i budynki przysługiwało prawo użytkowania udostępnionych mu zasobów na tych samych zasadach co ich właścicielowi, chyba że strony postanowiły w umowie inaczej $\left(\right.$ GII $220_{152}$ ). W szczególności dzierżawca miał prawo do produktywnego korzystania z wszelkich użytków zielonych należących do gospodarstwa, opału, w tym także szczególnie cennego węgla drzewnego (z zastrzeżeniem konieczności jego konserwowania) oraz składowania na terenie gospodarstwa własnych dóbr (GII 220 $\left.0_{151-153}\right)$.

Obowiązkiem dzierżawcy było z kolei zapewnienie odpowiedniej liczby domowników niezbędnych do w pełni produktywnego zagospodarowania oddanych mu w użytkowanie gruntów, dbanie o właściwy stan dzierżawionych budynków, a jeśli z gospodarstwem związane były także prawa dryftu (GII $209_{140-141}$ i $\left.G I I 218_{148-150}\right)$, to należyte ich wykonywanie i ochrona zasobów wyrzucanych na brzeg przed zajęciem przez osoby trzecie $\left(\right.$ GII $\left.220_{152-153}\right)$. Dzierżawcy nie było też wolno

${ }^{66}$ C. Callow, Iceland's Medieval Costal Market Places. Dögurðarnes in its Economic, Social and Political Context, w: Strandsteder, utvikinglingssteder og Småbyer $i$ vikingtid, middelalder og tidlig nytid ca. 800-ca. 1800, red. J. Brendalsmo, T. Gansum, F. Eliassen, Oslo 2010, s. 213-229.

${ }^{67}$ G. Sigurdsson, The North Atlantic Expansion, w: The Viking World..., s. 565.

68 B.E. Gelsinger, dz. cyt., s. 32.

69 J. Byock, dz. cyt., s. 269-270. 
poddzierżawiać gospodarstwa innym osobom, porzucić go przed upływem terminu umowy ani doprowadzić działaniem bąź zaniechaniem do spadku wartości gruntów o co najmniej pięć legalnych uncji. Każdy z tych czynów był zagrożony karą mniejszej banicji (GII $219_{150-151}$ ).

W odniesieniu do zwierzat gospodarskich staroislandzkie prawo przewidywało dwa rodzaje umów. Właściciel mógł je oddać w dzierżawę (GII $224_{166}$ ) bądź też przekazać je innemu gospodarzowi w utrzymanie (GII 224 ${ }_{167-168}$ ). Pierwsza z tych umów miała dla właściciela zwierząt charakter zarobkowy. W zamian za udostępnienie zwierząt dzierżawcy otrzymywał on od tego ostatniego wynagrodzenie w postaci renty dzierżawnej. Przeznaczeniem drugiej z nich było z kolei zminimalizowanie ryzyka związanego $\mathrm{z}$ utrzymywaniem $\mathrm{w}$ jednym miejscu dużej ilości zwierząt. Rozpraszając je pośród wiele odległych od siebie gospodarstw, gospodarz był stanie ochronić przynajmniej część z nich przed skutkami niebezpiecznych lokalnych zdarzeń losowych - trzęsień ziemi, pożarów, podtopień, pomorów ${ }^{70}$.

W przypadku obu wyżej wymienionych umów osoby przyjmujące zwierzęta były zobowiazane do dbania o nie „tak jak gdyby stanowiły one [ich W.G.] własność". Zapewniając zwierzętom odpowiednie warunki bytu, mogły one czerpać z nich korzyści, przede wszystkim w postaci mleka, jednakże bez prawa jego udostępniania osobom trzecim $\left(\right.$ GII $\left.224_{167}\right)$. Po upływie terminu umowy miały one z kolei obowiązek zwrócenia właścicielowi wszystkich zwierząt w równie dobrym stanie. Gdyby któreś z nich wcześniej zmarło, musieli oni przekazać w zamian za nie zwierzę o równej wartości. Przyjmujący dysponowali prawem zabicia zwierzęcia wyłącznie jeśli z uwagi na swoją kondycję fizyczną nie rokowało ono szansy na przeżycie zimy. Zaszlachtowanie dzierżawionego/przyjętego na utrzymanie zwierzęcia $\mathrm{z}$ innych powodów traktowano jako jawny zabór mienia znacznej wartości, to jest czyn zagrożony karą pełnej banicji (GII 224 $\left.{ }_{166-167}\right)$.

Maksymalną wysokość czynszu/renty dzierżawnej określono w staroislandzkim prawie na 10\% wartości przedmiotu umowy. Kwota ta stanowiła również najwyższa prawnie dopuszczalna wartość oprocentowania pożyczki (GII 221 155 ). Płatność miała nastapić w terminie i w miejscu określonym przez strony w umowie, przy czym zwykle dokonywano jej w trakcie wspólnego dla nich „wiecu do spraw długów” (skuldaping), tj. specjalnej sesji wiosennego zgromadzenia lokalnego. Jeśli strony nie porozumiały się co do „dnia spłaty” (eindagi), wówczas wierzyciel miał prawo do wezwania dłużnika z tygodniowym wyprzedzeniem, aby

\footnotetext{
70 Tamże, s. 269.
} 
przebywał w określonym czasie $\mathrm{w}$ gospodarstwie stanowiacym jego domicyl i przygotował na ten termin całość należnej kwoty $\left(\right.$ GII $\left.221_{159}\right)$.

Płatności czynszu, renty oraz oprocentowania dokonywano w środkach płatniczych określonych w umowie. Zazwyczaj był to samodział, staroislandzkie prawo dopuszczało jednak możliwość wykorzystania w tym celu krów mlecznych i owiec, surowej wełny, srebra, lisich skór (GII $221_{155}$ ) oraz gruntów rolnych i niewolników $\left(\right.$ GII $\left.221_{157}\right)$. W odniesieniu do szczególnie częstych transakcji przewidywano przy tym standardowe formy płatności. Dla przykładu zgodnie z jedna z zachowanych redakcji Grágás (GII $\$ 393_{343}$ ) opłata za dzierżawę jednej krowy mlecznej wynosiła 9 łokci samodziału jeśli dokonywano jej z góry lub 10 gdy uiszczano ją z końcem terminu umowy, za 20 owiec zaś jedną „miarę” (vcett) surowej wełny (jednostka wagi równoważna ok. $35 \mathrm{~kg}$ ).

Analiza treści staroislandzkich źródeł narracyjnych sugeruje, że u schyłku Pjódveldið czynsze i renty dzierżawne stanowiły główne (obok sprzedaży vaðmál) źródło dochodu bogatych islandzkich gospodarzy, a dokonywane w ramach ich uiszczania transfery dóbr były największą pozycją w wolumenie wewnętrznego obrotu gospodarczego ${ }^{71}$. Nie jesteśmy jednak w stanie określić, kiedy na Islandii wykształciła się instytucja dzierżawy. Zdaniem części badaczy mogło mieć to miejsce już u schyłku ery zasiedlenia ${ }^{72}$. Z końcem XI w. z cała pewnościa miała ona już istotne znaczenie gospodarcze, by najpóźniej w ostatnich dekadach XIII w. stać się dominująca formą gospodarowania. Około 100 lat później zdecydowaną większość islandzkich gospodarzy stanowili już dzierżawcy ${ }^{73}$.

W korpusie sag odnoszacych się do pierwszych 150 lat od zasiedlenia Islandii (tzw. Íslendingasögur) ${ }^{74}$ wzmianki na temat instytucji dzierżawy pojawiaja się bardzo rzadko. Jednymi z nielicznych postaci przedstawianych jako dzierżawcy w źródłach dotyczących okresu sprzed połowy XI w. sa Ásbjörn vegghamar z Fljótsdcela saga, Ingjaldr z Hergilsey z Gísla saga i Kálfr illviti z Bjarnar saga Hitdoelakappa. Zdaniem Jakoba Benediktssona niewielka liczba odniesień do umów dzierżawy w źródłach narracyjnych dotyczących okresu zasiedlenia i pierwszych dekad tzw. ery sag (söguöld, ok. 930-ok. 1030), nie powinna jednak

71 J. Jóhannesson, dz. cyt., s. 346-347.

72 J. Benediktsson, Some Problems in the History of the Settlement of Iceland, w: The Vikings, red. T. Andersson, K. Sandred, Stockholm 1978, s. 161-165; O. Vésteinsson, Patterns..., s. 17-27.

${ }^{73}$ S. Jakobsson, dz. cyt., s. 273-295.

${ }^{74}$ R. Gogosz, Sagi o Islandczykach (Íslendingasögur), w: Sagi islandzkie..., s. $15-39$. 
stanowić przesłanki do postawienia tezy, że instytucja leiga wykształciła się na Islandii dopiero później, a raczej być dowodem idealistycznego spojrzenia trzynasto- i czternastowiecznych sögumenn na życie swoich przodków ${ }^{75}$. O stosunkowo wczesnym rodowodzie dzierżawy wydają się świadczyć wyniki badań archeologicznych nad struktura zasiedlenia ${ }^{76}$, jak również pewne wzmianki w najstarszych islandzkich źródłach pisanych. W świetle uwag zawartych w Íslendingabók na temat majątku biskupa Gizzura Ísleifssona (1042-1118), na którego podstawie utworzono pierwsze islandzkie biskupstwo rezydencjonalne, nie ulega raczej wątpliwości, że najpóźniej w połowie XI w. najbogatsi Islandczycy dysponowali już kilkoma gospodarstwami, z których część była użytkowana przez dzierżawców ${ }^{77}$.

W przekazach dotyczących XII w., tak narracyjnych, jak i dokumentach w postaci np. aktów donacyjnych kościołów, możliwych do zidentyfikowania osób, dla których głównym źródłem dochodu są czynsze, jest już wiele, a część z nich dysponuje bardzo dużymi majątkami. Przykładami w tym względzie mogą być Steini Porvarðarson, który ok. 1143 r. podarował kościołowi w Stafholts siedem gospodarstw, z których sześć było dzierżawionych ${ }^{78}$, oraz Pórir Porsteinsson, który w świetle przekazów utrwalonych w uznawanej za relatywnie wiarygodne staroislandzkie źródło Sturlunga saga był właścicielem aż dziesięciu gospodarstw i miał wydzierżawiać majątek o równowartości stu mlecznych krów.

Sądząc po treści zachowanych sag, zyski czerpane z renty dzierżawnej i oprocentowania pożyczek cieszyły się znacznie większą akceptacja społeczną niż te pozyskiwane $\mathrm{z}$ handlu obwoźnego ${ }^{79}$. Njáll Porgeirsson, Gunnar Hámundarson czy Hrútur Herjólfsson, przedstawiani przez sögumenn jako powszechnie szanowani gospodarze, udzielali pożyczek znacznych kwot na procent, nie tracąc na swej popularności wśród innych boendr (zob. Njál saga, rozdz. 21, 66, 74). Wyższy stopień społecznej akceptacji dla tego rodzaju działalności, w porównaniu z utrzymywaniem się z wykorzystywania różnicy cen pomiędzy różnymi regionami (arbitrażu) - co jak się wydaje stanowiło główne źródło finansowego sukcesu znienawidzonego przez swych sąsiadów Hænsa-Pórira - był zapewne wynikiem jej silniejszego związania z gospodarką hodowlana,

75 J. Benediktsson, dz. cyt., s. 164.

${ }^{76}$ O. Vésteinsson, Patterns..., s. 17-27.

77 J. Jóhannesson, dz. cyt., s. 345.

${ }^{78}$ Diplomatarium Islandicum. Íslenzkt fornbréfasafn, t. 1, Reykjavík 1857, s. $179-180$.

${ }^{79}$ E. Durrenberger, The Dynamics of Medieval Iceland. Political Economy and Literature, Iowa City 1992, s. 66-67. 
jak również postrzegania czerpanych z niej zysków jako „naturalne”, co pozwalało odróżnić je od potępianej przez Kościół lichwy. Z tych tė̇ względów zakup użytków rolnych i zwierząt hodowlanych musiał jawić się bogatym średniowiecznym Islandczykom jako najlepsza z możliwych w lokalnych warunkach inwestycji ${ }^{80}$.

\section{Handel dalekomorski}

Renty dzierżawne i oprocentowanie pożyczek nie były jednakże jedynym społecznie akceptowalnym sposobem wzbogacania się na lokalnie dostępnych dobrach. Treść staroislandzkich źródeł nie pozostawia wątpliwości, że wielu Islandczyków regularnie uczestniczyło w dalekomorskich wyprawach handlowych. Jakkolwiek w świetle przekazów utrwalonych $\mathrm{w}$ sagach wyprawy te miały stanowić dla przedstawicieli elit społecznych przede wszystkim sposobność do zyskania na „honorze i reputacji”" ${ }^{1}$, nie ulega wątpliwości, że miały one także istotne znaczenie gospodarcze ${ }^{82}$.

Przez cały okres funkcjonowania Pjódveldið na Islandii nie wykształciła się osobna warstwa kupiecka, stąd też zagraniczne wyprawy handlowe musiały być organizowane przez członków rodów wodzowskich, z których znaczna część jeszcze długo po zmierzchu ery wikińskiej wydaje się dysponować pełnomorskimi statkami ${ }^{83}$. Dla „dobrze zapowiadających" się młodych mężczyzn (efniligir menn) z klasy najbardziej prominentnych boendr udział w tego rodzaju wyprawach stanowił swoisty obrzęd przejścia (zob. np. Ögmundar páttr dytts ok Gunnars helmings). W zagranicznym handlu brali jednak udział także mniej zamożni gospodarze oraz dysponujacy własnymi gospodarstwami duchowni, dla których dalekomorskie podróże były sposobnością do zakupu trudno dostępnego lokalnie chleba i wina eucharystycznego, wosku oraz szat i utensyliów liturgicznych ${ }^{84}$.

W czasach Pjódveldið głównym towarem eksportowym Islandii była owcza wełna, sprzedawana na zagranicznych rynkach bądź to w postaci

80 B.E. Gelsinger, dz. cyt., s. 29.

${ }^{81}$ H. Porláksson, Social Ideals and the Concept of Profit in Thirteenth-Century Iceland, w: From Sagas to Society. Comparative Approaches to Early Iceland, red. G. Pálsson, Enfield Lock 1992, s. 231-245.

${ }^{82}$ T. Carter, Iceland's Networked Society. Revealing How the Global Affairs of the Viking Age Created New Forms of Social Complexity, Leiden 2015, s. 271-277.

${ }^{83}$ B.E. Gelsinger, dz. cyt., s. 31-32.

${ }^{84}$ P. Urbańczyk, Zdobywcy..., s. 88. 
vaðmál, bądź też tzw. röggvarfeldir, tj. specjalnie plecionych okryć przypominajacych futra dzikich zwierząt ${ }^{85}$. Ponadto średniowieczni Islandczycy eksportowali też masło i sery, futra fok i arktycznych lisów, a od końca XII w. także siarkę wykorzystywana do produkcji „greckiego ognia” oraz suszone dorsze ${ }^{86}$. Okazjonalnie w staroislandzkich źródłach narracyjnych odnajdujemy również przekazy na temat wywożenia przez nich z kraju bardzo cennych białozorów (białych sokołów uchodzących za doskonałe ptaki myśliwskie ${ }^{87}$ oraz przybyłych na krach lub schwytanych na Grenlandii niedźwiedzi polarnych ${ }^{88}$.

Prowadzone $\mathrm{w}$ ostatnich latach badania archeologiczne wskazuja też, że Islandia była miejscem pozyskiwania cieszących się bardzo dużym zainteresowaniem na europejskich rynkach kłów arktycznych morsów, wykorzystywanych do produkcji wielu dóbr luksusowych. Najstarsze odkryte na wyspie punkty ekstrakcji kłów sa przy tym datowane na pierwsza połowę IX w., tj. na około pół wieku przed pierwszą dużą falą osadnicza, co sugeruje, że obietnica pozyskiwania tego cennego, a zarazem szeroko dostępnego lokalnie surowca mogła stanowić jeden z głównych bodźców ekonomicznych do skolonizowania tej odległej krainy ${ }^{89}$.

Głównym odbiorca islandzkiego eksportu w omawianym okresie była Norwegia ${ }^{90}$. Na bliskie związki ekonomiczne pomiędzy tymi krajami wpływ miało norweskie pochodzenie najbardziej prominentnych islandzkich osadników oraz uprzywilejowanie islandzkich kupców przez norweskiego władcę Olafa II Haraldssona, który ok. 1020 r. nadał Islandczykom przebywającym na terenie Norwegii prawa przysługujące höldr $\left(\text { GII } 248_{210-213}\right)^{91}$. W świetle treści zachowanych zwodów okręgu Gulen osoby legitymujące się tym tytułem znajdowały się na trzecim miejscu w hierarchii społecznej Norwegii, tuż po jarlu i lendmann, tj. arystokratach wchodzących w skład świty norweskiego władcy ${ }^{92}$. Powyższym relacjom o charakterze osobistym towarzyszył też obustronny interes

${ }^{85}$ B.E. Gelsinger, dz. cyt., s. 12.

86 J. Jóhannesson, dz. cyt., s. 313-317.

87 T. Carter, dz. cyt., s. 260.

${ }^{8}$ O. Vésteinsson, The Christianization of Iceland. Priest, Power and Social Change 1000-1300, Oxford 2000, s. 23.

${ }^{99}$ K. Frei, A. Coutu, K. Smiarowski i in., Was it for Walrus? Viking Age Settlement and Medieval Walrus Ivory Trade in Iceland and Greenland, „World Archaeology” 47, 2015, nr 3, s. 439-466.

90 J. Jóhannesson, dz. cyt., s. 310-317.

${ }^{91} \mathrm{P}$. Boulhosa, Icelanders and the Kings of Norway. Medieval Sagas and Legal Texts, Leiden 2005, s. 43-86.

${ }^{92}$ K. Maurer, Die norwegischen Höldar, München 1889, s. 169-207. 
ekonomiczny. Najbardziej poszukiwanym przez Islandczyków towarem było zboże, arcybiskup Niðaros, którego zwierzchnictwu islandzki Kościół podlegał od 1153 r., dysponował zaś przywilejem królewskim umożliwiajacym mu wysyłanie do Islandii ok. 50 ton pszenicy rocznie ${ }^{93}$.

Na przełomie XII i XIII w. za sprawą stopniowej utraty przez Islandczyków większości statków zdolnych do transoceanicznej żeglugi, spowodowanej seria katastrof morskich oraz brakiem lokalnego budulca szkutniczego, wymiana handlowa z Islandia została niemal całkowicie zdominowana przez norweskich kupców ${ }^{94}$. Rosnacy stopień uzależnienia gospodarki Pjódveldið od handlu z Norwegia został wykorzystany przez norweskich władców, którzy stosując groźbę embarga ekonomicznego, zdołali doprowadzić w połowie XIII w. do podporządkowania sobie pograżonych w lokalnym konflikcie Islandczyków i uczynili z zamieszkiwanej przez nich wyspy obszar trybutarny, gwarantując $\mathrm{w}$ zamian zachowanie stałości dostaw niezbędnych wyspiarzom dóbr ${ }^{95}$.

\section{Środki płatnicze i system cenowy}

Sögumenn pisząc o środkach płatniczych, za pośrednictwem których dokonywano transakcji gospodarczych na Islandii, używali zwykle słowa fé. Termin ten we współczesnych wydaniach sag tłumaczony jest najczęściej jako „pieniądze”, ale w zależności od kontekstu może tė̇ oznaczać „własność”, „kosztowności”, a także „zwierzęta hodowlane"96. Wielość znaczeń tego pojęcia odpowiada różnorodności środków, przy pomocy których średniowieczni Islandczycy dokonywali między sobą płatności. W różnych okresach, na różnych terenach i dla różnych transakcji w roli pieniędzy występowały bowiem na Islandii bardzo różne dobra: od srebra w postaci siekańców, kruszcu i monet, poprzez zwierzęta gospodarskie i pozyskiwane od nich produkty, aż po użytki rolne, narzędzia oraz niewolników ${ }^{97}$.

93 Diplomatarium..., t. 1, s. 225.

${ }^{94}$ B.E. Gelsinger, dz. cyt., s. 176-179.

95 Należy wszelako zaznaczyć, że kwestia tego, jak duży wpływ na upadek Pjóðveldið miało załamanie się zagranicznej wymiany handlowej jest w literaturze przedmiotem dyskusji; zob. B. Runólfsson-Solvason, Ordered Anarchy, State and Rent-Seeking. The Icelandic Commonwealth 930-1264, Fairfax 1991, mps rozprawy doktorskiej, s. 137-145, zwł. przywoływane tam pozycje.

${ }^{96}$ G. Zoëga, A Concise Dictionary of Old Icelandic, Toronto 2004, s. 132.

${ }_{97}$ S. Gullbekk, Money and Its Use in the Saga Society. Silver, Coins and Commodity Money, w: Viking Settlements \& Viking Society, red. S. Sigmundsson, Reykjavík 2011, s. 176-188; B.E. Gelsinger, dz. cyt., s. 34-36; J. Jóhannesson, dz. cyt., s. 328-335. 
Z treści staroislandzkich źródeł narracyjnych wynika, że w okresie wikińskim preferowanym przez Islandczyków środkiem płatniczym było srebro. Pamięć na temat jego dużej ilości w obrocie przetrwała wśród nich aż do XIII w., gdy zaczęto na Islandii na szerszą skalę spisywać sagi. Świadcza o tym liczne zawarte w nich odniesienia do rutynowych transakcji, jakie miały być dokonywane w okresie söguöld z użyciem różnych form tego kruszcu ${ }^{98}$. Przekonanie o jego szczególnej roli społeczno-gospodarczej znalazło również swe odzwierciedlenie w treści zbiorów prawa Pjódveldið, których redaktorzy konsekwentnie stosowali zabieg wyrażania wartości dóbr podlegajacych obrotowi oraz wysokości kar ich równowartością w srebrze. U schyłku funkcjonowania Wolnej Wspólnoty, gdy srebro zostało już wyparte jako główny środek płatniczy przez samodział, praktyka ta ewidentnie wymagała jednak uzasadnienia, stąd też w jednej z zachowanych kopii Grágás anonimowy trzynastowieczny skryba zdecydował się zamieścić swoista „,notę historyczna”. Jak przekonywał, „w czasach gdy chrześcijaństwo przybyło tu na Islandię [...] środkiem płatniczym dla regulowania wszystkich ważnych długów” było „białe srebro [bleikt silfr, chodzi najprawdopodobniej o srebro rafinowane - W.G.], zdolne do przejścia próby nacięcia” i bite w monety w taki sposób, by „srebro ważone i srebro liczone było tym samym" (GII $\left.245_{206}\right)$.

Nie jesteśmy w stanie określić, czy cytowana wyżej uwaga jest wyrazem historycznej wiedzy nieznanego nam redaktora zbiorów prawa, czy też raczej jego domysłów, niemniej jednak jego przekonanie, że przez ponad wiek od zasiedlenia wyspy srebro występowało na niej w ilościach umożliwiających stosowanie go w charakterze głównego środka płatniczego wydaje się być trafne. Islandczycy nie dysponowali wprawdzie lokalnymi złożami tego kruszcu, ani też własną mennica, ale jego duże ilości docierały na wyspę przez cały okres wikiński w postaci sztab, siekańców, zagranicznych monet oraz wyrobów rzemiosła artystycznego, jako pokłosie wypraw rabunkowych i handlowych. Świadczą o tym islandzkie źródła archeologiczne obejmujące znaleziska srebrnego złomu i pociętej biżuterii oraz 389 średniowiecznych monet z różnych regionów świata, w tym zwłaszcza z terenów Niemiec i Anglii, ale także Danii, Szwecji, Irlandii oraz Półwyspu Arabskiego ${ }^{99}$.

Potwierdzony archeologicznie fakt docierania do Islandii w okresie wikińskim znacznych ilości srebra per se nie stanowi oczywiście dowodu na to, że było ono lokalnie wykorzystywane w charakterze

\footnotetext{
98 S. Gullbekk, Money..., s. 184.

99 J. Jóhannesson, dz. cyt., s. 329.
} 
środka płatniczego. Kwestię tę dodatkowo komplikuje fakt, iż zdecydowaną większość wyrobów ze srebra odnalezionych na wyspie odkryto w kontekście ukrytych na niej „skarbów”. Przeznaczenie tych ostatnich jest przedmiotem wielu dyskusji w literaturze przedmiotu, a duża część podejmujących je badaczy upatruje wyjaśnienia ich fenomenu raczej w sferze symbolicznej niż gospodarczej ${ }^{100}$. Treść staroislandzkich źródeł, w których srebro często wykorzystywane jest do płatności dokonywanych $\mathrm{w}$ ramach wieców publicznych, nie może być uznana za rozstrzygajaca, zostały one bowiem spisane na długo po okresie, do którego się odnoszą i moga mieć charakter anachroniczny.

Niemniej jednak istnieja pewne przesłanki przemawiajace za przynajmniej częściową monetyzacją gospodarki wczesnej Islandii. Świadczyć może o tym zwłaszcza korzystnie wypadajace dla tej wyspy porównanie ilości odnalezionych na jej terenie jedenastowiecznych monet stanowiących tzw. luźne znaleziska z podobnymi odkryciami dokonanymi w Norwegii. Jedynym obszarem tego ostatniego kraju, gdzie znaleziono ich więcej niż na Islandii jest miasto Trondheim, w którym znajdowała się królewska mennica ${ }^{101}$. Spostrzeżenie to jest o tyle istotne, że luźne znaleziska monet, zwłaszcza noszących ślady poddawania ich próbom srebra w rodzaju tych opisanych w staroislandzkich źródłach, są zwykle uznawane w literaturze za dowód wykorzystywania ich w charakterze środka płatniczego w ramach lokalnej wymiany handlowej ${ }^{102}$. Nie bez znaczenia w tym względzie jest również fakt, że część owych luźnych znalezisk odnaleziono na Islandii na terenie pól wiecowych, na których zbierało się Zgromadzenie Powszechne, będące w świetle treści sag i Grágás tradycyjnym miejscem spłaty zobowiązań zaciagniętych między mieszkańcami odległych regionów wyspy oraz dorocznym targowiskiem, przyciagającym kupców i rzemieślników z kraju i zagranicy ${ }^{103}$. Jakikolwiek by jednak nie był poziom monetyzacji wczesnej gospodarki Pjóðveldið, nie ulega watpliwości, że srebro nigdy nie stanowiło jedynego legalnego środka płatniczego na Islandii, jak również że wraz z postępujacym procesem ograniczania jego dostępności na wyspie coraz większa część transakcji finansowych była zawierana przez Islandczyków przy pomocy różnych płacideł, w tym zwłaszcza powszechnie dostępnego, a zarazem cieszącego się dużym popytem u krajowych

${ }^{100}$ P. Urbańczyk, Causa deponendi wczesnośredniowiecznych „skarbów” srebrnych z pótnocnej Europy, w: Causa creandi. O pragmatyce źródła historycznego, red. S. Rosik, P. Wiszewski, Wrocław 2005, s. 605-618.

101 S. Gullbekk, Money..., s. 182-183.

102 Tenże, Coinage and Monetary Economies, w: The Viking World..., s. 166.

${ }^{103}$ S. Nordal, dz. cyt., s. 100. 
i zagranicznych kupców samodziału. Zjawisko stopniowego wypierania srebra przez vaðmál tłumaczone jest $\mathrm{w}$ literaturze przedmiotu przede wszystkim dobrze udokumentowanym w źródłach załamaniem się dopływu dużych ilości tego kruszcu na wyspę wraz ze zmierzchem ery wikińskiej ${ }^{104}$. Wydaje się jednak, że mogło ono mieć również przyczyny kulturowo-ekonomiczne, nie da się bowiem wykluczyć, że powszechne postrzeganie srebra jako pieniądza „lepszego” od samodziału doprowadziło z czasem do tezauryzacji kruszcu ${ }^{105}$.

Brak stałych źródeł pozyskiwania dostatecznej ilości cennych kruszców zmusił Islandczyków do rozwinięcia systemu pieniądza towarowego, w którym współistniało obok siebie wiele środków płatności ${ }^{106}$. Poza srebrem $\mathrm{w}$ formie zagranicznych monet, biżuterii i siekańców pierwsi Islandczycy wykorzystywali do zawierania transakcji płacidła w postaci lokalnie dostępnych dóbr, w tym zwłaszcza zwierząt gospodarskich oraz pozyskiwanych od nich produktów w postaci mięsa, mleka i jego przetworów, a także skór i wełny. Dla określenia ich adekwatnej wartości wymiar każdego z płacideł wiązano z jego ceną w srebrze ${ }^{107}$.

Ekwiwalentność środków płatniczych nie oznaczała jednak, że każda transakcja mogła zostać przeprowadzona przy pomocy dowolnego z nich. Obok lokalnej dostępności poszczególnych płacideł i czynników logistycznych (np. dystansu, jaki należało pokonać celem dokonania płatności, co było szczególnie istotne, gdy w charakterze środka płatniczego wykorzystywano zwierzęta) o przeznaczeniu każdego z nich decydowały bowiem względy kulturowe.

Płatności opiewajaccych na bardzo duże sumy, jak również spłaty grzywien i zadośćuczynień $\mathrm{w}$ miarę możliwości dokonywano przy pomocy srebra, w postaci monet bądź pierścieni, a w szczególnych okoliczności wyrobów ze złota. Powtarzalne transakcje zwykle były realizowane w samodziale, za zgodą odbiorcy płatności mogły być jednakże uiszczone także w produktach mlecznych, suszonych rybach, skórach różnych gatunków zwierząt oraz nieprzetworzonej wełnie i wyrobach z żelaza, takich jak kotły czy sierpy o standardowych wymiarach i odpowiedniej jakości ( $G I I 246_{207-210}$; $G I I \$ 430_{357-359}$ ). Lokalnie jako środki płatnicze wykorzystywano również zwierzęta gospodarskie, przede wszystkim mleczne krowy oraz owce, a rzadziej byki, konie, świnie i kozy.

104 B.E. Gelsinger, dz. cyt., s. 34-35.

${ }_{105}$ D. Friedman, Review: Icelandic Enterprise. Commerce and Economy in the Middle Ages, „The Journal of Economic History” 43, 1983, nr 1, s. 316.

106 J. Byock, dz. cyt., s. 45-46; S. Gullbekk, Money..., s. 179-180; J. Jóhannesson, dz. cyt., s. 331-335.

107 B.E. Gelsinger, dz. cyt., s. 34. 
Dla ich użycia w tym celu musiały one wszelako spełniać prawnie określone wymogi co do wieku, stanu zdrowia i zdolności do pokonywania dystansu dzielącego gospodarstwa stanowiace legalny domicyl stron (GII $246_{208-209}$. Nadto w odniesieniu do wprowadzonej pod koniec XI w. dziesięciny staroislandzkie prawo przewidywało możliwość uiszczenia jej części w wosku, kadzidle, smole, drewnie oraz tkaninach z lnu (GII 258 226 ).

Spośród wszystkich funkcjonujacych na Islandii form pieniądza towarowego zdecydowanie największe znaczenie miał samodział. O szczególnej roli vaðmál świadczy zwłaszcza fakt uczynienia zeń bazy dla tzw. legalnej uncji (lögeyrir, l. mn. lögaurar), będącej wspólnym denominatorem ${ }^{108}$. W świetle treści Grágás miało to stać się na mocy wydanej ok. 1100 r. ${ }^{109}$ „decyzji Zgromadzenia Powszechnego”, zgodnie z która jedna „legalna uncja” miała równać się „,sześciu łokciom właściwego samodziału, nowego i nieużywanego" (GII 246 $\left.{ }_{207}\right)$. Wartość lögeyrir pozostawała wszelako w ścisłym związku ze srebrem, przez co podlegała okresowym wahaniom. Na początku XI w. relacja między „legalna uncją" a uncją srebra kształtowała się na poziomie 8:1, w XII w. wynosiła 7,5:1, a w drugiej połowie XIII w. - 6:1 (odpowiednio 48, 45 i 36 łokci samodziału do uncji srebra $)^{110}$.

Określenie ekwiwalentnej wartości lögeyrir nie oznaczało centralnej kontroli nad cenami lokalnie dostępnych produktów. Treść staroislandzkich sag wskazuje bowiem, że te ostatnie były ustalane w drodze negocjacji między stronami transakcji ${ }^{111}$. W świetle dostępnych nam źródeł w całej historii Pjódveldið tylko raz doszło do prawnego ustalenia wartości dóbr podlegających obrotowi na terenie całego kraju. Miało to miejsce ok. 1200 r., kiedy Zgromadzenie Powszechne wydało listę z maksymalnymi cenami najpowszechniej obracanych na Islandii towarów. Lista ta miała obowiązywać przez rok i pod rygorem kary w postaci trzyletniej banicji wszystkich sprzedawców ${ }^{112}$. Akt ten nie ma wcześniejszych krajowych odpowiedników, nic też nie wskazuje, by później go odnawiano ${ }^{113}$, z tego też względu w literaturze przyjmuje się, że był

\footnotetext{
108 S. Gullbekk, Money..., s. 181.

109 Diplomatarium..., t. 1, s. 162-167.

110 J. Byock, dz. cyt., s. 54.

111 B.E. Gelsinger, dz. cyt., s. 38.

112 Diplomatarium..., t. 1, s. 318-319.

113 Znane sa wszelako listy z XII i XIII w. zawierające ceny krów ustalone podczas spotkań wieców lokalnych; zob. Diplomatarium..., t. 1, s. 265, 278, 282, 316, 420, 423. Sądząc jednak po ich wysokości, ceny te wydają się odzwierciedlać wahania wartości srebra i powiązanej z nim legalnej uncji.
} 
on jednorazową i nadzwyczajną reakcją na długotrwałą klęskę głodu, która dotknęła Islandię na przełomie XII i XIII w. wskutek załamania się warunków pogodowych oraz ograniczenia dostaw z Norwegii spowodowanego trwającym $\mathrm{w}$ tym kraju konfliktem wewnętrznym ${ }^{114}$.

Z treści staroislandzkich źródeł wynika natomiast, że stałej kontroli podlegały ceny towarów sprowadzanych na Islandię przez zamorskich kupców. Przez większość historii Wolnej Wspólnoty do jej sprawowania pretendowali lokalni wodzowie (goðar, l. poj. goði), którzy starając się narzucić zagranicznym przybyszom ceny sprzedawanych przez nich artykułów, chcieli uzyskać najlepsze warunki dla pierwokupu szczególnie interesujących ich produktów luksusowych (zob. np. Honsa-Póris saga, rozdz. 1; Brennu-Njáls saga, rozdz. 101; Íslendinga saga, rozdz. 15 i 35$)^{115}$. Posiadanie tych ostatnich znamionowało wysoki status społeczny, a ich dystrybucja poprzez dary była jednym z głównych sposobów pozyskiwania przez wodzów nowych i utrzymywania starych sprzymierzeńców w gronie wolnych gospodarzy ${ }^{116}$.

W świetle norm zawartych w Grágás pod koniec funkcjonowania Pjódveldið, gdy kraj był pogrążony w wewnętrznym konflikcie goðar o supremację nad całą wyspa, uprawnienia wodzów w zakresie kontroli cen zagranicznych produktów przejęli na siebie bliżej niezidentyfikowani forrádsmenn (,nadzorcy”), nie wiemy jednakże, kim oni byli ani jak ich wyznaczano. Niepodporządkowanie się ich decyzji obarczone było wszelako bardzo wysoką grzywną 12 marek, tj. czterokrotnie wyższa niż standardowa kara pieniężna przewidywana przez staroislandzkie prawo. Karę tę ponosił przy tym wyłącznie nabywca artykułów, sam kupiec wolny był od odpowiedzialności prawnej (GII $167_{92-93}$ ).

\section{Zakończenie}

Islandzka Pjódveldið stanowi „niemal unikalny przykład społeczności, której kultura i kreatywność rozwijała się już nawet nie w sytuacji braku sprzyjających warunków naturalnych, lecz w obliczu samych niemalże trudności”117. Ciężki klimat odizolowanej wyspy, w większości skutej przez zaschniętą lawę i lód, jak również wysoka średnia elewacja

114 J. Jóhannesson, dz. cyt., s. 321; B.E. Gelsinger, dz. cyt., s. 43.

115 J. Byock, dz. cyt., s. 255-260.

116 J.V. Sigurðsson, Friendship in the Icelandic Commonwealth, w: From Sagas to Society..., s. 209-210.

117 J. Bryce, Studies in History and Jurisprudence, t. 1, New York 1905, s. 263 (tłum. W.G.). 
terenu i niska jakość wulkanicznych gleb sprawiały, że średniowieczni Islandczycy musieli bardzo rozważnie gospodarować ograniczonymi zasobami. Po okresie zasiedlenia, kiedy ekspansja osadników miała rabunkowy charakter i doprowadziła do nieodwracalnych zmian w lokalnej faunie i florze ${ }^{118}$, mieszkańcy wyspy zaczęli stopniowo powracać do tradycyjnych nordyckich sposobów gospodarowania, podejmując przy tym starania zmierzajace do konserwacji szczególnie cennych dla nich zasobów, w tym zwłaszcza użytków zielonych i obszarów leśnych ${ }^{119}$. Uczynienie z chowu owiec i bydła głównego źródła dochodów islandzkich elit oraz prawne związanie większości Islandczyków pracą na roli doprowadziło wszelako w dłuższej perspektywie do utknięcia przez Islandię $\mathrm{w}$ pułapce równowagi (equilibrium trap) ${ }^{120}$ i rosnącego uzależnienia od zagranicznych dostaw. Zależność ta została wykorzystana w połowie XIII w. przez głównego partnera handlowego Islandczyków - Norwegię - do uczynienia z Islandii obszaru trybutarnego.

\section{Bibliografia}

Amorosi T., Buckland P., Edwards K., Mainland I., McGovern T., Sadler J., Skidmore P., They Did Not Live by Grass Alone. The Politics and Paleoecology of Animal Fodder in the North Atlantic Region, „Environmental Archaeology" 1, 1998, s. 41-54.

Byock J., Viking Age Iceland, London 2001.

Carter T., Iceland's Networked Society. Revealing How the Global Affairs of the Viking Age Created New Forms of Social Complexity, Leiden 2015.

Ciesielska A., Królestwo, państwo, wodzostwo czy system prawa ksiażęcego? $O$ formach organizacji spotecznych na etapie wczesnopaństwowym kilka uwag teoretycznych, „Studia Lednickie” 11, 2012, s. 47-58.

Diplomatarium Islandicum. Íslenzkt fornbréfasafn, t. 1, Reykjavík 1857.

Eggertsson P., No Experiments, Monumental Disasters. Why it Took a Thousand Years to Develop a Specialized Fishing Industry in Iceland, „Journal of Economic Behavior and Organization" 30, 1996, s. 1-24.

118 T. Amorosi, P. Buckland, A. Dugmore, J. Ingimundarson, T. McGovern, Raiding the Landscape. Human Impact in the Scandinavian North Atlantic, „Human Ecology” 25, 1997, nr 3, s. 491-518.

${ }^{119}$ O. Vésteinsson, I. Simpson, Fuel Utilisation in Pre-Industrial Iceland. A Micromorphological and Historical Analysis, w: Current Issues in Nordic Archaeology, red. G. Guðmundsson, Reykjavík 2004, s. 181-187.

${ }^{120}$ P. Eggertsson, No Experiments, Monumental Disasters. Why it Took a Thousand Years to Develop a Specialized Fishing Industry in Iceland, „Journal of Economic Behavior and Organization" 30, 1996, s. 1-24. 
Eggertsson P., Sources of Risk, Institutions for Survival, and a Game against Nature in Premodern Iceland, „Explorations in Economic History” 35, 1998, s. 1-30.

Frei K., Coutu A., Smiarowski K., Harrison R., Madsen C., Arneborg J., Frei R., Guðmundsson G., Sindbæk S., Woollett J., Hartman S., Hicks M., McGovern T., Was it for Walrus? Viking Age Settlement and Medieval Walrus Ivory Trade in Iceland and Greenland, „World Archaeology” 47, 2015, nr 3, s. 439-466.

Gelsinger B.E., The Icelandic Enterprise. Commerce and Economy in the Middle Ages, Columbia 1981.

Gogosz R., Sagi o Islandczykach (Íslendingasögur), w: Sagi islandzkie. Zarys dziejów literatury staronordyckiej, red. J. Morawiec, Ł. Neubauer, Warszawa 2015, s. 15-39.

Gullbekk S., Coinage and Monetary Economies, w: The Viking World, red. S. Brink, N. Price, London 2008, s. 159-169.

Gullbekk S., Money and Its Use in the Saga Society. Silver, Coins and Commodity Money, w: Viking Settlements \& Viking Society, red. S. Sigmundsson, Reykjavík 2011, s. 176-188.

Jakobsson S., From Reciprocity to Manorialism. On the Peasant Mode of Production in Medieval Iceland, „Scandinavian Journal of History” 38, 2013, nr 3, s. 273-295.

Jochens J., Women in Old Norse Society, Ithaca 1995.

Jóhannesson J., Íslendinga Saga. A History of the Old Icelandic Commonwealth, Winnipeg 1974.

Karras R., Slavery and Society in Medieval Scandinavia, New Haven 1988.

Keller C., Perdikaris S., The Northern Frontier - North Atlantic Farming During the Viking and Middle Ages, w: Agricultural and Pastoral Landscapes in Pre-Industrial Society, red. F. Retamero, I. Schjellerup, A. Davies, Oxford 2016, s. 37-55.

Landnámabók. The Book of Settlements, red. H. Pálsson, P. Edwards, Manitoba 1972.

Laws of Early Iceland. The Codex Regius of Grágás with Material from Other Manuscripts, red. A. Dennis, P. Foote, R. Perkins, Winnipeg 1980.

McGovern T., Perdikaris S., Einarsson Á., Sidell J., Coastal Connections, Local Fishing, and Sustainable Egg Harvesting. Patterns of Viking Age Inland Wild Resource Use in Mývatn District, Northern Iceland, „Environmental Archaeology" 11, 2006, nr 2, s. 187-205.

McGovern T., Vésteinsson O., Friðriksson A., Church M., Lawson I., Simpson I., Einarsson A., Dugmore A., Cook G., Perdikaris S., Edwards K., Thomson A., Adderley P., Newton A., Lucas G., Edvardsson R., Aldred O., Dunbar E., Landscapes of Settlement in Northern Iceland. Historical Ecology of Human Impact and Climate Fluctuation on the Millennial Scale, „American Anthropologist” 109, 2007, s. 27-51.

Perdikaris S., From Chiefly Provisioning to Commercial Fishery. Long Term Economic Change in Arctic Norway, „World Archaeology” 30, 1999, nr 3, s. 388-402. 
Perdikaris S., McGovern T., Cod Fish, Walrus, and Chieftains. Economic Intensification in the Norse North Atlantic, w: Seeking a Richer Harvest. The Archaeology of Subsistence Intensification, Innovation, and Change, red. T. Thurston, C. Fisher, Boston 2007, s. 193-216.

Perdikaris S., McGovern T., Viking Age Economics and the Origins Of Commercial Cod Fisheries in the North Atlantic, w: Beyond the Catch. Fisheries of the North Atlantic, the North Sea and the Baltic, 900-1850, red. L. Sickling, D. Abreu-Ferreira, Leiden 2008, s. 66-72.

Rutkowski R., „A ja nazywam się Ari”. O najstarszej kronice islandzkiej i jej autorze, w: Autor $i$ jego dzieło $w$ wiekach średnich, red. A. Laskowska, M. Sas, Warszawa 2014, s. 63-76.

Sagi islandzkie. Zarys dziejów literatury staronordyckiej, red. J. Morawiec, 七. Neubauer, Warszawa 2015.

Sigurðsson J.V., Chieftains and Power in the Icelandic Commonwealth, Odense 1999.

Simpson I., Adderley W., Guðmundsson G., Hallsdóttir M., Sigurgeirsson M., Snæsdóttir M., Soil Limitations to Agrarian Land Production in Premodern Iceland, „Human Ecology” 30, 2002, nr 4, s. 423-443.

Tomasson R., A Millennium of Misery. The Demography of the Icelanders, „Population Studies” 31, 1977, nr 3, s. 405-427.

Urbańczyk P., Causa deponendi wczesnośredniowiecznych „skarbów” srebrnych $z$ pótnocnej Europy, w: Causa creandi. O pragmatyce źródta historycznego, red. S. Rosik, P. Wiszewski, Wrocław 2005, s. 605-618.

Urbańczyk P., Na tropie pierwszego Islandczyka, w: Hominem quaerere. Człowiek $w$ źródle historycznym, red. S. Rosik, P. Wiszewski, Wrocław 2009, s. $69-77$.

Urbańczyk P., Zdobywcy pótnocnego Atlantyku, Torun 2012.

Vésteinsson O., The Christianization of Iceland. Priest, Power and Social Change 1000-1300, Oxford 2000.

Vésteinsson O., A Divided Society. Peasants and the Aristocracy in Medieval Iceland, „Viking and Medieval Scandinavia” 3, 2007, s. 117-137.

Vésteinsson O., Ethnicity and Class in Settlement-Period Iceland, w: The Viking Age. Ireland and the West, red. J. Sheehan, D. Ó Corráin, Dublin 2010, s. $494-510$.

Vésteinsson O., Patterns of Settlement in Iceland. A Study in Pre-History, „Saga Book” 25, 1998, s. 1-29.

Porarinsson S., Iceland in the Saga Period. Some Geographical Aspects, w: Priðji Víkingafundur, red. K. Eldjárn, Reykjavík 1958, s. 13-24.

Porláksson H., Social Ideals and the Concept of Profit in Thirteenth-Century Iceland, w: From Sagas to Society. Comparative Approaches to Early Iceland, red. G. Pálsson, Enfield Lock 1992, s. 231-245. 
Włodzimierz Gogłoza

The Icelandic Economy during the Commonwealth era (Summary)

Iceland was settled during the Viking Age by a multi-ethnic group of settlers whose most prominent members came from Norway. Initially the settlers relied mainly on hunting, fishing and egg harvesting for their survival. However, from the tenth century the Icelanders turned to more traditional Nordic farming strategies based around cattle production and sheep-herding. The focus on animal husbandry was reflected in the medieval Icelandic social structure, in which the highest strata were occupied by the members of the householders class. The so-called bondr earned their living from livestock and provided employment for the landless members of the society. The household farm was the basic unit of production, and the basic unit of work. While the goal of the household economy was self-sufficiency, both the written and archaeological sources confirm that various goods, including food, fodder, and prestige items, circulated in large quantities between households. Most of the domestic circulation of goods occurred in the context of exchanges regularized in credit and tenancy relationships, but there is also evidence in the sources for internal trade carried out at fairs and temporary marketplaces. The most important products of the Icelandic economy during the Commonwealth era were freshwater fish, meat and milk from cattle, and wool obtained from sheep. Wool, being readily available and easily transported over long distances, quickly became the staple of Icelandic export. Eventually it replaced silver as a medium of exchange and it became a standard for purchase, inheritance, rents and legal payments. Despite large profits that could be obtained by trading woolen products abroad, Iceland did not develop the merchant class, and over time became increasingly dependent on foreign trade conducted by Norwegians. This dependency was one of the driving factors of Iceland becoming a tributary area of Norway in the thirteenth century.

Włodzimierz Gogłoza - adiunkt na Wydziale Prawa i Administracji Uniwersytetu Marii Curie-Skłodowskiej w Lublinie. Jego zainteresowania badawcze koncentrują się wokół społeczności przedpaństwowych, policentrycznych systemów prawnych, ustroju średniowiecznej Islandii oraz historii myśli organizatorskiej.

Włodzimierz Gogłoza - assistant professor of law at the Faculty of Law and Administration of the Maria Curie-Sklodowska University. His research interests include: pre-state societies, polycentric constitutional orders, medieval Icelandic legal system, and the history of the organizational and managerial thought.

E-mail: wgogloza@poczta.umcs.lublin.pl. 